\title{
Do We Pronounce Quotation? An Analysis of Name-informing and Non-name-informing Contexts
}

Language and Speech 2020, Vol. 63(4) 769-798

(C) The Author(s) 2019

Article reuse guidelines: sagepub.com/journals-permissions DOI: $10.1177 / 0023830919893393$ journals.sagepub.com/home/las

@SAGE

\section{Marcel Schlechtweg (DD}

University of Kassel, Germany

\section{Holden Härtl}

University of Kassel, Germany

\begin{abstract}
Quotation marks are a tool to refer to the linguistic form of an expression. For instance, in cases of so-called pure quotation as in "Hanover" has three syllables, they point to the syllabic characteristics of the name of the town of Hanover. Cases of this nature differ from sentences like Hanover is a town in New Hampshire, in which Hanover is used denotationally and, thus, refers to the town of Hanover itself. Apart from quotation marks, other means such as italics, bold, capitalization, or air quotes represent potential means to signal a non-stereotypical use of an item in the written or gestural mode. It is far less clear, however, whether acoustic correlates of quotation marks exist. The present contribution aims at investigating this issue by focusing on instances of quotation, in which the conventionalized name of a lexical concept is highlighted by means of quotation marks, either together with or without an additional lexical quotational marker, such as so-called, on the lexical level (cf. The so-called "vuvuzela" is an instrument from South Africa vs. The "vuvuzela" is an instrument from South Africa). The data clearly show that quotation marks are pronounced, primarily triggering a lengthening effect, independently of whether they appear together with or without a name-informing context. The results of the experiments are interpreted against the background of a pragmatic implementation of quotation marks in general as well as in spoken discourse in particular.
\end{abstract}

\section{Keywords}

Acoustic correlates, implicature, name informing, quotation, quotation marks 


\section{Introduction}

Speakers sometimes talk about language; that is, they mention linguistic material alongside or instead of using it denotationally. In example (1a), the phrase through pass is used with its default denotation. In (1b), however, the phrase is, apart from being used denotationally, mentioned. The quotation marks, or "quotes" for short, emphasize its use as a fixed term for a concrete complex lexical concept:

(1) a. Jeff got a through pass and scored the next goal.

b. Jeff got a "through pass" and scored the next goal.

Quotation marks are thus a common indicator of the mentioning use of an expression. However, mentioning can also be signaled by other means; for example, through a name-mentioning modifier like so-called, which, in turn, can occur on its own (see 2a) or together with quotation marks (see 2b):

(2) a. Jeff got a so-called through pass and scored the next goal.

b. Jeff got a so-called "through pass" and scored the next goal.

While the name-mentioning use of through pass is indicated by means of quotes alone in (1b), this function is adopted by so-called in (2a). In (2b), the two devices appear and highlight the namementioning function together.

The two aforementioned strategies to introduce name mentioning, quotation marks, and socalled, differ, however, in a trivial but crucial respect: whereas it is indisputable that the modifier so-called can appear both in written documents and in spoken discourse, it is far less clear whether quotation marks also have a correlate in spoken language. Hence, the central goal of this contribution is to investigate whether quotation marks are realized acoustically. For this purpose, occurrences of quotation marks in instances of quotation as those illustrated in (1b) and (2b), which have so far been widely neglected in the literature on quotation in spoken language, are examined. The second objective of our analysis is to find out whether quotation which is lexically encoded in a name-informing context, as illustrated in (2b), can be acoustically distinguished from cases with no name-informing context, as in (1b). "Name-informing context" refers here to the presence of a name-informing marker on the lexical level. Such lexical markers include, among others, predicates like to call or modifiers like so-called. ${ }^{1}$ Finally, we are also interested in analyzing whether quotation without quotation marks in written language has nevertheless acoustic correlates in speech. Answers to the latter question will give us new insights on the semantic or pragmatic status of quotes.

The structure of the present paper is as follows. Section 2 discusses the semantics and pragmatics of quotation. Different types of quotation are discussed before we focus on the meaning of one specific kind of quotation, namely name-mentioning quotation. We further reflect upon whether markers of quotation, such as quotation marks in written language use, are merely optional or whether they are decisive in quotational contexts of the sort under discussion. On the pragmatic side, we interpret different types of markers, quotation marks, air quotes, and so on, as triggers of a manner-based implicature. In the remainder of our study, we concentrate on quotation in spoken language. Section 3 summarizes and analyzes the available literature on quotation in spoken discourse. Results from previous work draw a mixed picture and research has so far primarily concentrated on one type of quotation, namely quotation used in reported speech. Using the state of the art 
as a point of departure, Section 4 outlines and interprets two new production studies in which we investigated the acoustics of quotation marks in name-informing and non-name-informing contexts. Based on the results of these studies, we argue that quotation marks are clearly acoustically realized and play a crucial pragmatic role for the speaker.

\section{Semantics and pragmatics of quotation}

Quotation is a metalinguistic device used to talk about language (see, e.g., Davidson, 1979, p. 27; Recanati, 2001, p. 639; Saka, 1998, p. 129). Thus, in quotational constructions, an expression is mentioned rather than or in addition to being used denotationally, which means reference is made to the shape of the quoted expression (see, e.g., Quine, 1981, pp. 23-26). For instance, with an assertion like "Hanover" has three syllables, in contrast to Hanover is a town in New Hampshire, the syllabic setup of the word Hanover is described and the quotes around Hanover indicate this use.

\section{I Quotational constructions and their meaning}

In the literature on quotation, five main types are commonly distinguished (see 3; for overviews, see, e.g., Brendel, Meibauer, \& Steinbach, 2011a, b; Cappelen \& Lepore, 2012; Saka \& Johnson, 2017):
(3) a. "Hanover" has three syllables.
b. "Something is wrong," Max whispered.
c. Tom said he planned to climb Mount Kilimanjaro.
d. The coach declared that his team would "kick arse" today.
e. The "beach" was in fact a thin strip of black volcanic grit.

The example in (3a) is an instance of pure quotation, which is used to denote linguistic objects and display the shape of an expression in a rule-like fashion (see, e.g., Ginzburg \& Cooper, 2014, p. 291; Maier, 2014). In pure quotation, no specific utterance or speech event is designated, which Cappelen and Lepore (2007) claim to be a key difference between pure quotation, on the one hand, and direct (see 3b) and indirect (see 3c) as well as mixed quotation (see 3d), which is a combination of direct and indirect quotation, on the other. Scare quotation as used in (3e) has a distancing function and expresses a specific speaker modality implying a certain reservation with respect to the semantic appropriateness of the expression in quotes (see, e.g., Meibauer, 2007; Predelli, 2003).

Quotation can also be used to mention the conventionalized name of a lexical concept. ${ }^{2}$ Consider the example in (4):

\section{(4) Blood poisoning is also called "septicemia."}

We consider quotations of the type in (4) as instances of pure quotation. The quotational construction informs the addressee that a specific name is commonly used (in this case septicemia) to refer to a certain denotatum, namely blood poisoning. Name-mentioning predicates like call- require a quoted name as their complement. The verbal root involves three thematic arguments: an agent $x$ and a theme $y$ (blood poisoning), as well as the name $z$ (septicemia) of the theme $y$. In (5), we represent the name as an argument of a relational function.

(5) $x$ call $-y z$

$\exists e[\operatorname{CadL}(e) \& \operatorname{Agent}(x, e) \& \operatorname{Theme}(y, e) \& \operatorname{Name}(z, y, e)]$ 
Observe that the name argument of call- can also be saturated by an anaphor; for instance, by so, as is illustrated in the following example:

(6) The doctor diagnosed septicemia ${ }_{i}$. Blood poisoning is called so in $_{i}$ medical terms.

Here, the so, with its demonstrative function (see Umbach \& Gust, 2014), points to an occurrence of an expression, septicemia, in the preceding sentence. This expression is identified with the name argument of call- (see Cappelen \& Lepore, 1999, p. 748). In the participial form of the predicate, as exemplified in (7) below, the so is morphologically incorporated and points to the head noun of the host NP:

The doctor diagnosed so $_{i}$-called septicemia ${ }_{i}$.

Thus, with so-called as a modifier, septicemia is mentioned (as a pure quotation) and used denotationally (as the direct object of diagnose) at one and the same time in this case (see Härtl, 2018). ${ }^{3}$

The quotational constructions in (4) to (7) above fulfill a name-informing function. In contrast, a quotation as illustrated in (8), while also mentioning a name, adopts a distanced interpretation instead of a name-informing one:

\section{Ann had a very bad experience at the so-called "hotel."}

Constructions of this sort are instances of scare quotation. So-called has a modalizing function here and gives rise to an ironic, non-literal reading of the expression in quotes. In this instance, the modifier is semantically related to the meaning of intensional, privative attributes like pretend or fake, which also enforce a shift from the literal denotation of the noun they modify (see, e.g., Schumacher, Brandt, \& Weiland-Breckle, 2018). Note that, as is argued in Härtl (2018), the so in so-called and quotation marks are identical in their function as both point to linguistic shapes. The tendency to use both quotational means, as in the example in (8), can be seen as a reflector of the producer's strategy to "play it safe" and, thus, to ensure the intended reading (Finkbeiner, 2015, p. 164).

A demonstration-based analysis of quotational so has a natural fit with Davidson's Demonstrative Theory of quotation (Davidson, 1979). Its central claim is that quotation is an operation through which a linguistic shape is referred to by pointing to something that has this shape. In this way, a quotation refers to the expression inside the quotes reflexively (see, e.g., Ludwig \& Ray, 2017, p. 102). The criticism raised against demonstration-based approaches towards quotation often points out that quotes are optional and that it is, in fact, not the quotes that do the quotation. Saka (1998, p. 118), for example, states that a quotational construction as in (9a), without quotes around the mentioned expression, is grammatical and not ill-formed:

(9) a. Cats is a noun.

b. "Cats" is a noun.

In the same way, Washington (1992) argues that quotation marks (as well as their gestural and acoustic equivalents) are not an essential part of a quotational construction. On his account, quotes are no more than a punctuation device and, as such, "are neither mentioning expressions nor parts of mentioning expressions" (Washington, 1992, p. 591). Approaches of this sort imply that quotes are not "semantic" in the sense that their manifestation is not part of the compositional semantic representation of a quotational construction. Instead, quotes are considered pragmatic in nature. A 
pragmatic view is also maintained in more recent analyses like De Brabanter's (2013), who, with a focus on mixed quotation, argues that contextual clues alone are sufficient to pragmatically construe a quotational meaning with no need to signal the quotation with a dedicated linguistic marker. Under such a view, quotation marks are claimed to be not a necessary ingredient in both the written and spoken mode.

We believe that it is still an open question whether the presence of quotes is essential in a quotation or not. Proponents of a semantic analysis of quotes often claim the presence of quotes to have truth-conditional effects (see Predelli, 2003; Simchen, 1999). Furthermore, on a semantic account, the optionality of quotes can be motivated with the quoted material's contextual embedding, which in many cases is sufficient to generate a mentioning reading of an expression (see Cappelen \& Lepore, 1999, p. 743). Note that such a view predicts additional processing costs for quotational constructions without quotes. The example in (9a) can be used to illustrate this as it appears indeed to be somehow unusual, in comparison to (9b). In (9b), the quotation marks indicate that Cats refers, in this case, to a linguistic characteristic of the name of the concept of cATs and not to the concept's extension itself. (9a) is striking because there is no marker that explicates this use here. An example as in (10a) is even more obscure, as In can be neither the syntactic subject nor the semantic argument of is a preposition (see Brendel, Meibauer, \& Steinbach, 2011a, p. 14):

(10) a. In is a preposition.

b. "In" is a preposition.

Quotation marks seem to facilitate processing to a critical extent not only in pure but also in other types of quotation; for example, in mixed quotation and the interpretation of indexicals therein (see Cappelen \& Lepore, 2012; Cumming, 2003; McCullagh, 2007 for discussion). Consider the following examples:

(11) a. Zach said that we would win the game in our stadium.

b. Zach said that we would win the game in "our stadium."

In (11b), the quotation marks signal mixed quotation; our, in this case, refers to a group-for instance, a soccer team that necessarily includes Zach. If the quotation is dropped (see 11a), this is no longer the case; our can designate a group including Zach and the writer of the sentence at the same time, or a group to which only the writer but not Zach belongs.

The above examples illustrate that by omitting quotes in quotational constructions "much inferential burden will be passed onto the addressee or the interpreter" (Wang, 2018, p. 119). As Saka (1998, p. 129) puts it, the presence of quotation marks "indicates a metalinguistic use; their absence does not necessarily indicate anything at all." Further, Christensen (1967, pp. 359-360) maintains that, while a sentence like Hanover has three syllables may itself be unambiguous, the omission of quotes introduces a homonym. The intended meaning needs to be resolved contextually as Hanover refers to the linguistic shape of the word in this case and not to the standard denotation. Based on this observation, Christensen (1967, pp. 359-360) acknowledges that the use of quotation marks in a systematic fashion as in "Hanover" has three syllables is functional in the sense that it prevents the creation of homonyms. As García-Carpintero (2011, p. 110) in a critical discussion of the Identity Theory of quotation (see, e.g., Washington, 1992) states, quotation marks "serve to make clearer the shift in syntactic and semantic properties effected on the quoted material by its occupying that linguistic context."

While the meaning of quotation is well defined, we believe it to be an open question whether quotation marks are an essential part of the compositional semantic representation of a quotational 
construction or not. Note that the absence of graphemic quotes alone does not entail that there is no semantic equivalent of quotes, constructed by the addressee through contextual inference. Alternatively, quotes can also be assumed to function as conventionalized but optional pragmatic attachments, used in conversation to generate markedness of the quoted expression, akin to, for example, intonational markers commonly used to signal irony (e.g., What wonderful weather for a picnic! when it is raining heavily).

\subsection{Pragmatics of quotation}

Quotational settings can be established in different ways. First, quotation can be indicated by certain grammatical markers. An example is the use of the conjunctive I in German as a signal of indirect quotation; compare Tom sagt, sie esse gerade "Tom says she is eating" (see, e.g., Klockow, 1980, p. 93; see also Brendel et al., 2011a, pp. 10-11). Second, lexical means can be used as indicators of quotation. Verbs of saying, preceding, or following a direct quotation (see $3 \mathrm{~b}$ above) signify reported speech (see, e.g., Brendel et al., 2011a, p. 11). Further, modifiers like so-called point to the name of the modified noun (see 7 and 8 above). Apart from the aforementioned grammatical and lexical categories, there are several mode-specific techniques to mark quotation. As typographical means, quotes materialize as inverted commas by default, but also as italics, bold print, underlining, capitals, and others (see, e.g., Davidson, 1979, p. 27; Klockow, 1980, p. 14; Quassdorf, 2016, p. 78; Washington, 1992, p. 590). ${ }^{4}$ In the gestural mode, quotation is often encoded by means of air quotes (see, e.g., Bennett, 1988, p. 400). Finally, quotation can be assumed to be expressed in spoken language, but it is far from clear whether quotation is systematically expressed in specific acoustic features. We will come back to this point in Section 3.

The information generated by quotes and quotational constructions is often considered to be rooted in pragmatic principles in the literature. Pragmatic approaches towards quotation commonly analyze quotes as markers of a deviation from the standard use of an expression (see, e.g., Klockow, 1978). We follow Klockow (1980) in utilizing the Gricean conversational maxims to account for the function of quotes as an indicator of a deviation from the linguistic norm (see Härtl, 2018). In a similar fashion, Meibauer (2007), Gutzmann and Stei (2011), and Finkbeiner (2015) implement quotes as pragmatic markers that give rise to a non-stereotypical interpretation of the expression in quotes. The central idea of accounts of this nature is that the additional marking of an expression can be understood to trigger a manner-based implicature along the lines of Levinson's M-principle. The principle holds that a non-stereotypical meaning is indicated by using a marked expression that contrasts with the expression used to describe a default meaning (see Levinson, 2000, pp. 136-137). Crucially, such an approach towards the function of quotes is applicable to all varieties of quotation, including name-informing and distancing quotation (see 7 and 8 above). In both cases, quotes are used to signal a deviation from the canonical use of the expression in quotes. In name-informing quotation, quotes highlight the use of the expression as a name as well as its status as a conventionalized name; in distancing quotation, the use of quotes indicates a departure from the literal meaning of the expression.

In quotational constructions in which the type of quotation is not explicated lexically, its function needs to be deduced through pragmatic inferencing. Consider these examples:

(12) a. The "iamb" is a unit of two syllables with the accent on the second.

b. The "garden" is an ill-kept lawn with a couple of trees.

The interpretations of the quotes differ in the two examples. They fulfill a name-informing function in (12a), whereas the quotes in (12b) indicate a non-literal meaning of the subject noun; that 
is, they are instances of scare quotes used to indicate irony. In Härtl (2018), it is argued that, besides contextual clues, the lexical frequency of the quoted material is a factor guiding the inferential process. In avoidance of an R-principle violation (see Grice, 1975), a high-frequent noun like garden adopts a non-literal meaning due to the fact that the noun is highly conventionalized and, thus, name-informing quotes are perceived as irrelevant with it. In contrast, with low-frequent nouns like $i a m b$, the use of quotes indicating the status of the quoted noun as a conventionalized name for a metrical foot is pragmatically appropriate.

While the semantic and pragmatic fundamentals of quotation are well investigated, its correlate(s) in spoken language is a widely understudied topic. In particular, it is an open question whether quotes and their materialization, respectively, are a necessary part of an utterance containing a quotation and we believe an investigation into the acoustic properties of quotational constructions to be insightful in this respect. Three main questions are of interest: one concerns the acoustic materialization of quotes in general. Do quotes have an acoustic correlate? A second question is whether quotes are realized differently in quotational and non-quotational contexts. Finally, we ask whether quotes are acoustically expressed in quotational contexts even if the mentioned expression is used without (written) quotes. Only if evidence is found for the latter, we can assume the explication of quotes to be obligatory in a quotational construction.

\section{Quotation in spoken language: the state of the art}

In the non-empirical literature on quotation, it is often assumed that quotation marks do not have an acoustic correlate or that no systematic acoustic correlate of quotation marks has been discovered (see, e.g., De Brabanter, 2017, p. 246; Klockow, 1980, p. 80; Recanati, 2001, p. 661). In the absence of spoken quotes, speakers do not mark quotation at all in spoken discourse or have to rely on grammatical or lexical markers alone, such as the statements "Quote" at the beginning and "Unquote" at the end of a quotation (see, e.g., Bennett, 1988, p. 400; Davidson, 1979, p. 27). There are, however, several studies that have concentrated on the subject. Their findings and implications for quotation in spoken language are discussed in the following.

The first observation in this context is that most of the research has so far focused on direct and indirect quotation. Based on data from conversational exchanges, Couper-Kuhlen (1998) argues that a speaker has different means at his or her disposal to implement direct quotation, or to integrate the words of another speaker into his or her own discourse and to differentiate between the words of more than one quoted speaker. Among these parameters, one finds, for instance, fundamental frequency (F0), intensity, segment duration, tempo, voice quality, or rhythm (see also, e.g., Günthner, 1997, pp. 238-239; 1999). Her central claim is that a speaker deviates from the default values that characterize his or her own speech if another speaker is imitated. Higher F0 is one example of how such a speaker shift can be modulated. Klewitz and Couper-Kuhlen (1999) examined the prosodic design of direct quotation in English conversational interactions. It was shown that direct quotation could prosodically differ from the surrounding context in that it could show, for example, a higher F0, higher intensity, isochronous timing of the accented syllables, and/or longer pauses at its beginning. Moreover, the analysis revealed that language users adapted their speech in order to distinguish between words attributed to one original speaker and words attributed to another speaker. Overall, Klewitz and Couper-Kuhlen (1999) emphasize, however, that, first, direct quotation was not consistently marked in the aforementioned way and that, second, indirect quotation, too, could be marked in a similar manner (see also Günthner, 1997, p. 241). Therefore, based on this study, it seems premature to argue that direct quotation is expressed in a systematic fashion in spoken language (see also Sams, 2010). Using data from speeches given to an audience by experienced speakers, Lampert (2018) looked at potential correlates of direct 
quotation, such as pause durations, F0, or intensity, in English, but did not find a coherent and systematic picture of how quotation is realized in spoken language. Studying data from spontaneous interviews, Oliveira and Cunha (2004) examined whether the boundaries of directly quoted sequences are expressed acoustically in Brazilian Portuguese. Comparing theses boundaries to other, non-quoted-context boundaries, their analysis revealed that characteristics such as longer pauses, higher F0, or higher intensity signaled direct quotation. Jansen, Gregory, and Brenier (2001) examined the prosodic correlates of direct and indirect quotation in English using speech from the Switchboard corpus. They showed that the F0 range was greater for direct than for indirect quotation, which, in turn, did not differ from non-quoted narrative speech. Further, Jansen et al. (2001) found evidence that direct but not indirect quotation occurred with an increased F0 range in comparison to the preceding elements outside the quotation. For French, investigating data from a family conversation, Bertrand and Espesser (2002) contrasted several F0 parameters across: (a) direct quotation of a speaker; (b) indirect quotation with utterances from a person different from that speaker; and (c) indirect quotation with utterances from the speaker referred to in (a). The authors found, for example, that the mean F0 values did not differ between (a) and (b) but between (c) and the two others. It seems thus that indirect quotation is realized differently if it refers to different speakers. Cervone, Lai, Pareti, and Bell (2015) used a corpus containing telephone conversations to investigate possible prosodic cues of direct and indirect quotation. It was shown, for example, that direct quotation occurred with greater F0 ranges than indirect quotation and nonquoted sequences and that indirect quotation differed from non-quoted structures in terms of intensity. In sum, the aforementioned contributions investigated whether direct and indirect quotation is reflected acoustically. The findings, however, are rather mixed and do not point to a clear picture. While some authors did not detect specific acoustic correlates of quotation, others found that pause durations, F0, and/or intensity are manipulated in quotation. These potential correlates of quotation will be considered again in the discussion of the experiments in Section 4.

Leaving direct and indirect quotation aside, one recognizes that research on the acoustics of other types of quotation is non-existent, with one exception. Focusing on German, Kasimir (2008) investigated whether subclausal quotation marks were expressed and recognized in spoken language. Specifically, she examined the following three kinds of quotation:

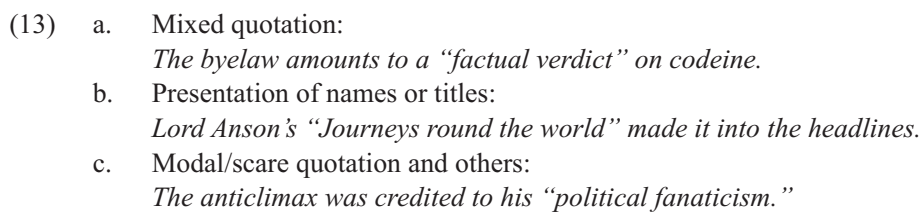

(Kasimir, 2008, p. 71)

Four experiments are reported in Kasimir (2008). In the first one, eight subjects read out written sentences with quotation marks, as those in (13), or the same sentences without quotation marks. In a second task, four participants were provided with pairs of written sentences - each pair consisting of a sentence without quotation marks and the same sentence with quotation marks - as well as the oral productions of these sentences and were asked to state which written and spoken sentences belonged together. In a third task, two raters were exposed to the recordings of the read sentences. For each sound file, they had to decide whether the original written sentences contained quotation marks or not. Finally, in a fourth task, subjects were asked to translate several spoken sentences into written language, by deciding whether quotation marks had to be present or not. Kasimir's (2008) analysis revealed that approximately 64\% of the cases in the second and third tasks were classified correctly. This finding suggests that written quotation marks have correlates 
in spoken language. Although this is an interesting finding, the contribution leaves several questions open and has a limited scope. First of all, it is not clear why the sound files gathered in the first task, the production experiment, were not analyzed acoustically with the help of a speech software. Instead, the data was only evaluated on the basis of the author's perceptual impression. It is unlikely that such a methodology suffices to detect subtle differences in the acoustics of quoted and non-quoted utterances. Even if one intends to rely on a perceptual judgment, a detailed analysis has to be provided. Such an analysis is, however, missing. Second, although the second and third tasks indicate that quotation marks are pronounced because they are apparently perceived, the significance of these tasks is very limited as only four and two subjects were tested here. Third, theoretical issues of quotation are almost entirely ignored in the paper. It is, for instance, unclear what other kinds of quotation were included in the third category exemplified in example (13c) above as the author calls them "other / modal uses" (Kasimir, 2008, p. 71). Put differently, the question arises what "other" means here. Overall, while Kasimir's (2008) investigation offers some interesting points and looks at types of quotation other than direct and indirect quotation, it suffers from several shortcomings that prevent us from drawing a clear conclusion.

In sum, apart from Kasimir's study, experiments that have so far examined whether quotation is articulated concentrated on direct and indirect quotation and showed mixed results. Hence, it is necessary, on the one hand, to further investigate the acoustics of quotation in general, and, on the other hand, to examine whether another type of quotation, such as name-informing quotation, is pronounced. The following experiments aim at filling this gap in the literature.

\section{Quotation in spoken language: experimental evidence}

\section{I Experiment I}

4.I.I Type of study, research questions, and hypotheses. The study presented in this section was a production experiment, in which participants were asked to read out sentences that contained nouns embraced by quotation marks or the same sentences with no quotation marks around the nouns. It aimed, first of all, at examining whether quotation marks are pronounced. Second, the study tested whether two kinds of quotation with a name-informing function, namely quotation with a name-informing function within a name-informing context and quotation with a nameinforming function without a name-informing context, differ in how they are phonetically realized. ${ }^{5}$ Quotation marks might be pronounced more strongly in name-informing contexts than in non-name-informing contexts because name-informing contexts contain a double mentioning realized through the quotation marks and the name-informing context at the same time. Alternatively, quotation marks might be pronounced more strongly in non-name-informing contexts than in name-informing contexts because they are the only tool in non-name-informing contexts that signals that the noun is mentioned, and not simply used denotationally as in the non-quoted context. In contrast, in name-informing contexts, the noun is mentioned anyway, with and without quotation marks. Finally, quotation marks in name-informing and non-name-informing contexts might be pronounced in a comparable manner, although they adopt a slightly different function. In nonname-informing contexts, they represent the only means that signals that the noun in question is mentioned. In name-informing contexts, in turn, they intensify or double the mentioning of the noun. The third question to be addressed was whether quotation is nevertheless acoustically expressed if no quotation marks are present in written language and if only the context indicates that an expression is mentioned. Based on the aforementioned options, the following hypotheses were stated: 
Hypothesis 1: Quotation marks are pronounced in that nouns with quotation marks differ in all or some of the acoustic parameters to be introduced below from the same nouns (in the same environment and context) without quotation marks.

Hypothesis 2: Quotation marks in name-informing and those in non-name-informing contexts are pronounced in a different way.

Hypothesis 3: Quotation is also articulated if no quotation marks are present in the written mode.

\section{I.2 Method}

4.I.2.I Subjects. Eight native speakers of German (five females, three males), all of whom were university students from different fields of study, participated in the study (mean age: 27.1, standard deviation age: 3.1, age range: 24-33). None of them had a speech disorder and all had normal or corrected-to-normal vision. None of the subjects participated in Experiment II, which is reported in Section 4.2.

4. I.2.2 Materials. The eight German target nouns given in (14) were examined in the experiment:

(14) Kapern “capers," Pappel "poplar," Kutte “robe," Kippa "kippah,” Koppel "paddock," Kate “cottage," Kiepe "pannier," Puppe "cocoon"

All nouns were disyllabic, carried primary stress on the initial syllable, and started with an open syllable. Further, the first syllable consisted of a voiceless plosive in onset position and a vocalic rhyme. The second syllable, also, always began with a voiceless plosive. The target nouns were of low frequency to ensure the name-informing function of quotation (see Section 2.2). Highly frequent nouns should not appear in a name-informing context as they are too conventionalized to be explicitly introduced as the name of a lexical concept. Hence, nouns of high frequency tend to be interpreted in an ironic or distancing way if presented with quotation marks and/or namementioning predicates or modifiers. The nouns of the study therefore belong to a frequency class higher than frequency class 10 in the Wortschatz (vocabulary) corpus of the German language (wortschatz.uni-leipzig.de/de). Note that the frequency class of an item reflects its frequency in comparison to the frequency of the most frequent German word, the masculine definite article (der). While the highly frequent word der, for example, is part of frequency class 0 , the test item Kiepe ("pannier") is part of frequency class 19.

The nouns were tested in the following four conditions: (a) no quotation marks but nameinforming context; (b) quotation marks and name-informing context; (c) no quotation marks and non-name-informing context; and (d) quotation marks but non-name-informing context. All nouns appeared in a target sentence in all conditions; the target sentence, in turn, was preceded by a context sentence. The context and target sentences for the noun Kiepe "pannier" in the four conditions are given in (15), the context and target sentences in which the other items occurred are presented in Appendix A:

(15) a. Diese korbähnliche Transporttasche für den Rücken erleichtert die Arbeit in der Landwirtschaft. Man nennt sie Kiepe unter Bauern.

"This basket-like bag for the back facilitates the work in agriculture. One calls it pannier among farmers."

b. Diese korbähnliche Transporttasche für den Rücken erleichtert die Arbeit in der Landwirtschaft. Man nennt sie ,Kiepe“ unter Bauern.

"This basket-like bag for the back facilitates the work in agriculture. One calls it 'pannier' among farmers." 
c. Diese korbähnliche Transporttasche für den Rücken erleichtert die Arbeit in der Landwirtschaft. Man kennt die Kiepe unter Bauern.

"This basket-like bag for the back facilitates the work in agriculture. One knows the pannier among farmers."

d. Diese korbähnliche Transporttasche für den Rücken erleichtert die Arbeit in der Landwirtschaft. Man kennt die „Kiepe“ unter Bauern.

"This basket-like bag for the back facilitates the work in agriculture. One knows the 'pannier' among farmers."

The nouns appeared in the same and in a central position in the target sentences of all conditions. The context sentence was the same across the four conditions. ${ }^{6}$ The target sentence was identical for (15a) and (15b) on the one hand and for (15c) and (15d) on the other hand, except for the fact that the noun was not surrounded by quotation marks in (15a) and (15c) but in (15b) and (15d). The target sentences containing a name-informing predicate (15a and $15 \mathrm{~b}$ ) were identical to the target sentences without name-informing predicate (15c and $15 \mathrm{~d})$ with respect to the segmental character, the only difference being the initial segments of the predicates ([n] in nennt versus [k] in kennt) and the initial segments of the word preceding the target noun ([s] in sie versus [d] in die). Crucially, these minor differences did not appear in the direct neighborhood of the target nouns as the phones that immediately preceded and followed the target nouns were identical across all conditions.

4.I.2.3 Procedure. The experiment was conducted in a silent room. The participants were seated in front of a large diaphragm condenser microphone, which, in turn, was placed in front of an elevated computer screen. Subjects saw the context and target sentence together on the screen, read them silently first, and, finally, read them aloud. They were recorded with Praat (Boersma \& Weenink, 2017).

Subjects read all of the 8 target nouns in the 4 conditions introduced above; that means everybody produced a total of 32 experimental cases. Since all speakers produced all sentences in all conditions, each participant served as his or her own control and the critical factor of inter-subject variation was controlled for. Crucially, the order of the four conditions was counterbalanced by means of a Latin Square Design. As all subjects read all sentences in all conditions, this was an important step in order to keep the influence of repetitions constant across all conditions. Repetitions could otherwise distort the picture as they typically lead to a more comprised articulation (see, e.g., Chamberland, SaintAubin, \& Légère, 2013). In addition, 64 filler cases were integrated in the experiment in order to increase the distance between an experimental sentence with a target noun in one condition and an experimental sentence with the same target noun in another condition and, hence, to reduce potential repetition effects again. Twenty-three other experimental and filler cases appeared between a specific item (e.g., Kiepe) in one condition and the same item in another condition. The item order varied across participants. The experiment lasted for about 20 to 25 minutes per person.

The presentation of the sentences on the computer screen was the same across the four conditions; for instance, all words of the examples given in (15a-d) appeared in exactly the same position on the screen in all conditions. The target noun, either with or without quotation marks, never appeared at the beginning or end of a line. Other formal issues, such as spacing, font, or font size, were also identical across the four conditions.

4. I.3 Data analysis. After the recording, a Praat text grid was used to segment and annotate the data. The analysis focused on the target noun, specifically on the stressed and first syllable of the target noun. In this syllable, in turn, the following five intervals were considered and the following seven dependent variables were measured (see Table 1 and Figure 1): 
Table I. Intervals and dependent variables.

\begin{tabular}{ll}
\hline Interval & Dependent variable \\
\hline Syllable & Duration of syllable $\left(D_{s}\right)$ \\
Plosive & Duration of plosive $\left(D_{p}\right)$ \\
Constriction & Duration of constriction of plosive $\left(D_{C}\right)$ \\
Voice onset time (VOT) & VOT of plosive \\
Vowel & Duration of vowel $\left(D_{v}\right)$ \\
& Maximum FO of vowel $\left(F 0 \max _{\mathrm{v}}\right)$ \\
& Maximum intensity of vowel $(\operatorname{lmax})$ \\
\hline
\end{tabular}

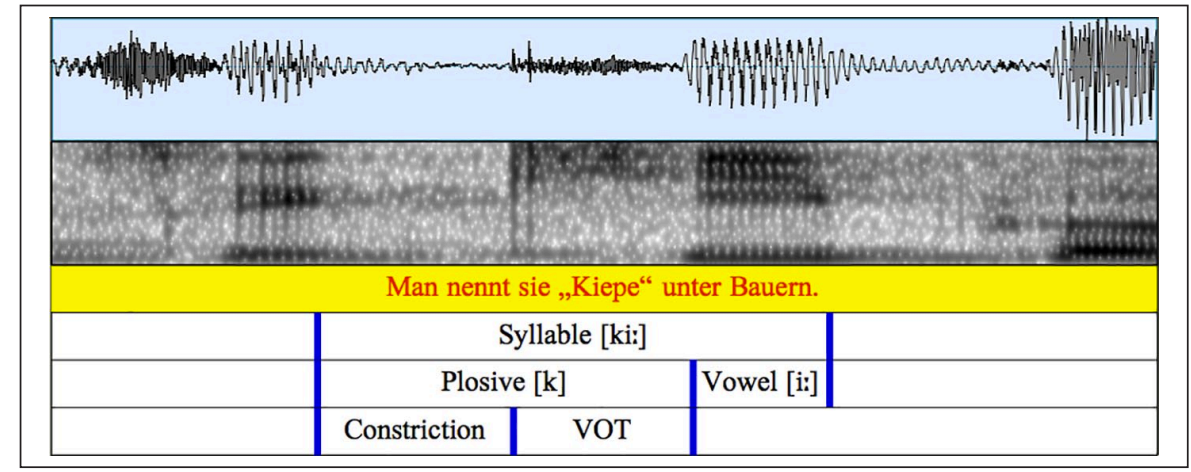

Figure I. Intervals used in the analysis.

Note: The quotation marks here and in the experimental studies in general are presented in the way in which they are conventionalized in German, that is, with low marks before the noun and high marks after the noun.

Before considering these intervals in more detail, a note on the segmentation of the data is in order. As mentioned above, a vowel preceded the target syllables of the target nouns in the test sentences. The target syllables, in turn, consisted of a voiceless plosive and a vowel. Another voiceless plosive followed the target syllable (see 16 with the target syllable underlined and Figure 1):

(16) Man nennt sie "Kiepe“ unter Bauern.
zi: 'ki:po

The voiceless plosive of the target syllable, underlined in (16), had to be separated from the preceding (e.g., the first [i:] in 16) and the following vowel (e.g., the second [ii] in 16). In addition, the vowel of this syllable had to be separated from the next voiceless plosive. It is well known that the aforementioned sequences of vowels and consonants can be typically segmented in a reliable way (see, e.g., Turk, Nakai, \& Sugahara, 2006, p. 5). The specific segmentation criteria used in the present study and described below were based on the characteristics of the speech sounds in focus and segmentation strategies presented in the literature (see Ladefoged, 2003; Machač \& Skarnitzl, 2009; Pätzold \& Simpson, 1997; Reetz \& Jongman, 2009; Turk et al., 2006). The end of the vowel preceding the target syllable (e.g., the first [i:] in 16 above) was set at the beginning of the constriction of the voiceless plosive (e.g., [k] in 16). A clear loss of energy in the second formant (F2) visible in the spectrogram was the primary criterion to detect the boundary between the aforementioned vowel and the constriction. A considerable loss of energy in the third formant (F3), the first 
formant (F1), and an abrupt decrease in amplitude were regarded as further signals of the vowelconstriction boundary. If the four criteria (loss of energy in F2, loss of energy in F3, loss of energy in F1, drop in amplitude) did not coincide, priority was given to the F2 criterion (see, e.g., Ladefoged, 2003, p. 141; Turk et al., 2006, p. 7). If F2 could not be reliably spotted in the spectrogram, the next criterion, the loss of energy in F3, was used as the primary criterion, and so on and so forth. The onset of the plosion of the voiceless plosive recognizable in the waveform and/or spectrogram was considered the beginning of the VOT. The boundary between the end of the VOT and the beginning of the vowel of the target syllable (e.g., the second [i:] in 16) was then identified through the sudden increase of energy in F2. The reverse strategy of the one described above for the vowel-constriction sequence was applied here (drastic rise in energy in F2, F3, F1, and a clear expansion of the amplitude). Finally, the end of the vowel of the target syllable was separated from the beginning of the constriction of the following plosive by applying the procedure used for the first vowel-constriction sequence above. All boundaries were placed at the nearest zero crossing in the waveform.

The intervals and dependent variables listed earlier were motivated on the basis of the following ideas and findings. First of all, several durational measurements were included in a hierarchical manner. Specifically, it was initially examined whether the entire target syllable differed in duration in the different environments, such as quoted and non-quoted contexts. Next, the locus of a potential effect was specified, which means it was investigated whether it was rooted in the syllable onset, namely in the plosive, and/or in the nucleus. The objective of this step was to see "how far" the target syllable was possibly affected in different conditions. For example, quotation marks could only trigger a lengthening of the next segment after the marks, namely the plosive, of both segments, or of the nucleus only. Finally, it was verified whether the two phases of the plosive could be distinguished in duration. Preferring plosives rather than other consonants had the advantage of being able to break down the analysis even further.

Strictly speaking, duration measurements can reflect two phenomena in the present case, either a hesitating or an emphasizing behavior. The constriction of the plosive, the first phase of the target noun (e.g., Kiepe in 16) after the preceding word (e.g., sie in 16), falls in the first category. Hesitating is assumed here to be similar to pausing. In the non-empirical literature, pauses have been suggested as possible acoustic markers of quotation (see, e.g., Bennett, 1988, p. 400; Brendel et al., 2011a, p. 9; Harth, 2011, p. 202). Klewitz and Couper-Kuhlen (1999, p. 22) claim that a pause can represent a "suspenseful delay." Not only in non-empirical but also in empirical works have pauses been connected to the topic of quotation. Specifically, Oliveira and Cunha (2004) found longer pauses in the environment of direct quotation in comparison to non-quoted contexts. In the current analysis, it was tested whether specific conditions, such as quoted contexts, lead to a more expanded constriction or hesitation. While the plosive constriction was regarded as a mirror of a hesitating behavior, a longer VOT and vowel duration were considered possible expressions of a higher emphasis/prominence in a specific condition; for instance, in a quoted in comparison to a non-quoted part. It is well known that a higher degree of prominence can be acoustically realized by means of a longer duration of segments or segment parts (see, e.g., Kupisch \& Lleó, 2017; Lehiste, 1970; Lein, Kupisch, \& van de Weijer, 2016, p. 734; Lisker \& Abramson, 1964, p. 414; 1967). Hence, extended VOTs or longer vowels were regarded as sources of higher prominence.

Not only duration but also F0 and intensity can signal differences in prominence (see, e.g., Kunter, 2011, p. 57-69; Lehiste, 1970; Terken \& Hermes, 2000). Therefore, these two parameters were also included in the current analysis in order to see whether the target vowels are articulated more prominently in specific environments; for example, if they are preceded by quotation marks.

Apart from the above-named reasons, the available empirical literature on the acoustics of quotation presented in Section 3 further supported the idea to consider both the pausing and 
the emphasizing behavior in the conditions under investigation. Some of the empirical studies discussed in Section 3, for instance, showed that F0 and/or intensity were higher and pauses longer in quoted than in non-quoted contexts. All of these analyses, however, have so far been applied to direct and indirect quotation only. It remains to be examined whether other types of quotation behave similarly in this respect.

Note further that, in the case of F0, maximum values of each case/vowel were calculated, rather than the mean F0 of a vowel or the F0 at the mid-point of a vowel, because it was assumed that maxima represent the actual pitch contour more accurately (see Kunter, 2011, pp. 74-75). Since outliers, which would distort the picture of maximum values, were discarded (see below for detailed information) and since the target nouns were not associated with boundary tones, maxima were considered a reliable representation of F0. For reasons of consistency, the maxima were also investigated in the intensity analysis.

The five duration measurements were obtained from the waveform, and $\operatorname{Imax}_{\mathrm{V}}$ was calculated with the "Get maximum intensity" function in Praat. F0 $\max _{V}$ was measured with the "Get maximum pitch" function and Praat's autocorrelation method. For females, a range of 100 to $500 \mathrm{~Hz}$ was chosen, for males a range of 75 to $300 \mathrm{~Hz}$ was preferred.

The seven dependent variables were analyzed in the following way. ${ }^{7}$ First of all, statistical outliers were discarded for each dependent variable by implementing a boxplot analysis (Larson-Hall, 2010 , p. 245). In boxplots, all values from the 25 th to the 75 th percentile are summarized within a box, the so-called interquartile range. The median is represented by a solid line in the box. Whiskers, vertical lines extending out from the top of the box on the one side and the bottom of the box on the other side, reach the minimum and maximum values of a dataset. However, values that occur at a point that is more than "one and a half times the length of the box" (Larson-Hall, 2010, p. 245) away from the edge of the box are considered statistical outliers. Outliers in the raw dataset of each dependent variable were spotted in a boxplot and subsequently removed. The final dataset of raw values of each dependent variable included at least $96 \%$ of the original data.

In the next step, for each of the seven dependent variables, two repeated-measures ANOVAs, a subject (F1) and an item analysis (F2), were conducted using the mean values of each subject and item in each condition. The independent and fixed factors Quotation marks (with/without) and Name-informing context (yes/no) and their interaction, as well as the random factors Subject (F1) and Item (F2), were included in the model. Both of the fixed factors were within-subject and within-item factors.

4. I.4 Results. A main effect of Quotation marks was found for four of the seven dependent variables: $\mathbf{D}_{\mathbf{S}}, F 1(1,21)=13.85, p=.001 ; F 2(1,21)=14.47, p=.001 ; \mathbf{D}_{\mathbf{P}}, F 1(1,21)=15.26$, $p=.001 ; F 2(1,21)=21.02, p<.001 ; \mathbf{D}_{\mathbf{C}}, F 1(1,21)=6.45, p=.019 ; F 2(1,21)=12.29$, $p=.002 ;$ VOT, $F 1(1,21)=28.51, p<.001 ; F 2(1,21)=33.50, p<.001$. That is, nouns with quotation marks were pronounced with a longer target syllable, plosive, constriction, and VOT than the same nouns without quotation marks. Further, the analysis revealed a main effect of Name-informing context for two of the seven dependent variables: $\mathbf{D}_{\mathbf{C}}$, in $F 2$ only, $F 2(1,21)=$ $4.53, p=.045$ and $\mathbf{F 0 m a x} \mathbf{V}, F 1(1,21)=31.45, p<.001 ; F 2(1,21)=42.98, p<.001$. That is, the nouns in name-informing contexts were uttered with a longer constriction and a vowel with a higher F0max than the same nouns in non-name-informing contexts. The descriptive statistics of the dependent variables are presented in Table 2. Note that, for reasons of conciseness, only values that reached significance are listed here.

An interaction of Quotation marks $\times$ Name-informing context was found for one of the seven dependent variables: $\mathbf{F 0 m a x}$, in $F 2$ only, $F 2(1,21)=4.74, p=.041$. The post-hoc comparisons of the significant interaction are represented in Table 3. Two aspects can be observed here. First, 
Table 2. Descriptive statistics.

\begin{tabular}{llllll}
\hline Condition & $D_{S}$ & $D_{P}$ & $D_{C}$ & VOT & FOmax $_{V}$ \\
\hline Q & $233(18)$ & $171(15)$ & $83(10)$ & $89(13)$ & \\
NQ & $234(40)$ & $171(9)$ & $83(9)$ & $89(15)$ & \\
NIC & $222(16)$ & $162(13)$ & $78(10)$ & $82(12)$ & \\
NNIC & $222(36)$ & $162(12)$ & $78(11)$ & $82(14)$ & $197(44)$ \\
& & & & & $197(15)$ \\
& & & $79(10)$ & & $184(50)$ \\
\hline
\end{tabular}

First line for each condition: Subject analysis (mean, standard deviation in brackets); second line for each condition: Item analysis (mean, standard deviation in brackets).

$\mathrm{D}_{\mathrm{S}}$ : duration of syllable (in $\mathrm{ms}$ ); $\mathrm{D}_{\mathrm{p}}$ : duration of plosive (in $\mathrm{ms}$ ); $\mathrm{D}_{\mathrm{C}}$ : duration of constriction of plosive (in ms); VOT: voice onset time of plosive (in ms); FOmax without quotation marks; NIC: name-informing context: NNIC: non-name-informing context.

Table 3. Post-hoc comparisons of the interaction of Quotation marks $\times$ Name-informing context $\left(\mathrm{FOmax}_{\mathrm{V}}, \mathrm{F}_{2}\right)$.

\begin{tabular}{lrr}
\hline Comparison & $t_{1}\left(t_{2}\right)$ & $p_{1}\left(p_{2}\right)$ \\
\hline I. Q + NIC vs. NQ + NIC & -0.73 & .884 \\
2. $\mathbf{Q}+$ NIC vs. Q + NNIC & 3.10 & .026 \\
3. Q + NIC vs. NQ + NNIC & 5.44 & $<.001$ \\
4. NQ + NIC vs. Q + NNIC & 3.83 & .005 \\
5. NQ + NIC vs. NQ + NNIC & 6.18 & $<.001$ \\
6. Q + NNIC vs. NQ + NNIC & 2.35 & .119 \\
\hline
\end{tabular}

Note: For each significant difference, the group with higher F0 values is highlighted in bold. Significant values are also highlighted in bold.

Q: nouns with quotation marks; NQ: nouns without quotation marks; NIC: name-informing context; NNIC: non-nameinforming context.

the significance levels show that the difference between the two name-informing-context conditions is smaller than the difference between the two non-name-informing-context conditions (see comparisons 1 and 6 in Table 3). Second, again expressed in the significance levels, the difference between name-informing and non-name-informing contexts is smaller if the nouns of both groups are surrounded by quotation marks in comparison to if no quotation marks occur at all (see comparisons 2 and 5 in Table 3; see also Figure 2).

4.I.5 Discussion. The first experimental study clearly shows that nouns highlighted with quotation marks are pronounced differently from the same nouns without quotation marks. Specifically, it was shown that the target syllable was lengthened if preceded by quotation marks. The analysis of the other dependent variables subsequently revealed that only the onset, and not the nucleus, of the syllable was concerned: only the syllable-initial plosive, and not the following vowel, was critically lengthened. Within the plosive, in turn, both the constriction and the VOT were subject to the lengthening process. Since the context in which the nouns were presented was identical, the main effect of Quotation marks is reliable and cannot be explained on the basis of other factors. 


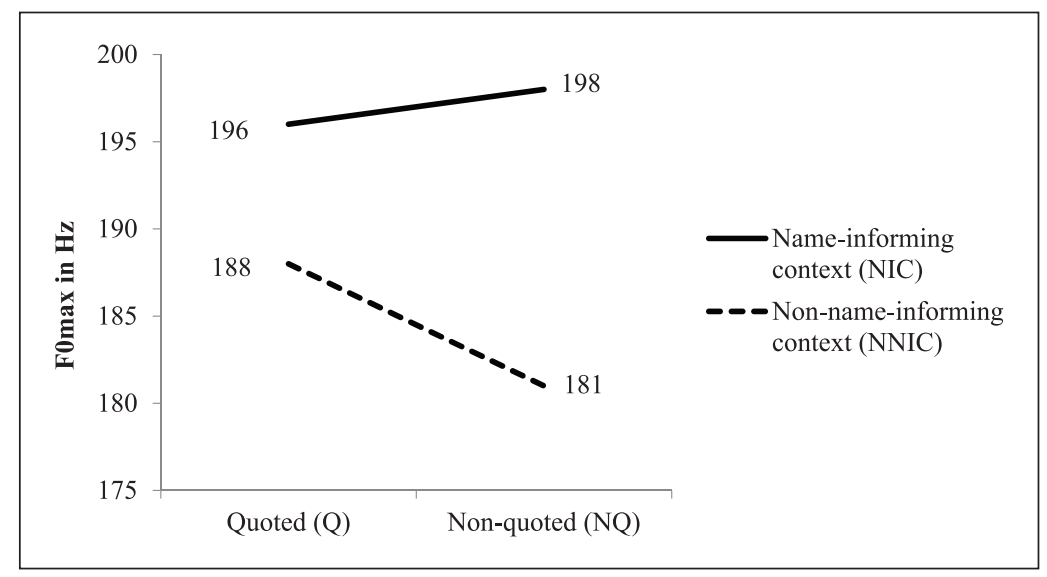

Figure 2. Significant interaction of Quotation marks $\times$ Name-informing context $\left(\mathrm{FOmax}_{\mathrm{v}}, \mathrm{F}_{2}\right)$.

The examination further indicated that nouns in name-informing contexts were uttered differently from the same nouns in non-name-informing contexts. It could be shown that name-informing contexts caused both a longer constriction of the syllable-initial plosive and a higher F0max in the syllable nucleus. However, at this point, these effects have to be treated with caution for two reasons. First, the syntactic environment differed between name-informing and non-name-informing contexts. That means, while the target noun was part of a single noun phrase in the latter (e.g., Man kennt die Kiepe unter Bauern. "One knows the pannier among farmers"), it was not in the former (e.g., Man nennt sie Kiepe unter Bauern. "One calls it pannier among farmers"). Second, sie ("it") in name-informing contexts anaphorically referred back to the preceding context sentence, in this case to Diese korbähnliche Transporttasche für den Rücken ("This basket-like bag for the back"). Die ("the"), in turn, did not do that in the non-name-informing contexts. Based on the first experiment reported here, it is not entirely clear whether the effect derives from the nameinforming context or rather from the syntactic and discourse-related aspects just referred to. The follow-up study reported in Section 4.2 eliminated these confounding factors.

Apart from the two main effects, the statistical analyses also revealed a significant interaction between the two independent variables. The post-hoc analyses showed that there was almost no difference between the F0max of the target vowel in the name-informing conditions with and without quotation marks. Although the difference between the non-name-informing conditions with and without quotation marks was still non-significant, it was clearly greater. A potential explanation might be the fact that nouns in name-informing contexts are mentioned anyway, independently of whether or not quotation marks accompany the items. In the non-name-informing contexts, however, nouns are only mentioned if surrounded by quotation marks; otherwise, they are only used denotationally. Hence, it might be the case that the distinction between mention and use is reflected in the F0max of the vowels of the nouns.

Finally, the post-hoc comparisons of the significant interaction further showed that the difference between name-informing and non-name-informing contexts is larger if no quotation marks occur around the nouns in comparison to if quotation marks are used. On the one hand, one might argue that this derives from the use-mention distinction again. That means, the fact that nouns are mentioned in name-informing (without quotation marks) but used denotationally in non-name-informing contexts (without quotation marks) might be reflected in the F0max of these nouns. Since nouns are 
mentioned in either context if quotation marks are present, the difference between the two quoted conditions can be expected to be smaller. On the other hand, however, quotation marks might also reduce the influence of the syntactic and/or discourse-related aspects discussed above. This would also explain why name-informing and non-name-informing contexts differ more from each other in terms of F0max if no quotation marks are present. In order to clarify whether the interaction is reliable at all and, if so, where the roots of this interaction are located, we used a different lexical quotational marker in the second experimental study.

\subsection{Experiment II}

4.2.I Type of study, research questions, and hypotheses. The type of study, research questions, and hypotheses were the same as in Experiment I. However, Experiment II went beyond Experiment I in four crucial respects. First, a different lexical quotational marker was embedded in the test sentences to ensure that the syntactic structure of the name-informing and non-name-informing contexts is identical this time. Second, no context sentences were used to avoid potential differences in the information structure of the name-informing and non-name-informing contexts. Third, a larger number of subjects was recruited to increase the explanatory power of our work. Fourth, the data analyses were significantly expanded in order to evaluate more concisely where potential acoustic effects operate. This time, we did not only consider the first syllable of the target noun but also the syllable before this noun, the second syllable of this noun, and the syllable after this noun. This is outlined in detail in Section 4.2.3.

\subsubsection{Method}

4.2.2.I Subjects. Sixteen female native speakers of German, all of whom were university students from different fields of study, participated in the study (mean age: 22.3, standard deviation age: 3.6, age range: 19-31). None of them had a speech disorder and all had normal or correctedto-normal vision. None of the subjects had participated in Experiment I.

4.2.2.2 Materials. The eight German target nouns given in (17) were examined in the experiment:

(17) Kaper "caper," Pappel "poplar," Kutte "robe," Kippa "kippah," Koppel "paddock," Kuppe “tip/peak," Pita "pita," Pauke "timpani"

All nouns were disyllabic, carried primary stress on the initial syllable, and started with an open syllable. Further, the first syllable consisted of a voiceless plosive in onset position and a vocalic rhyme. The second syllable was composed of a voiceless plosive and a vowel or syllabic consonant (in the following, we call the rhyme of the second syllable simply "vowel"). The target nouns were of low frequency and belong to a frequency class higher than frequency class 10 in the Wortschatz (vocabulary) corpus of the German language.

The nouns were tested in the four conditions already introduced for Experiment I. All nouns appeared in a target sentence in all conditions. This time, there was no context sentence that preceded the target sentence. The sentences for the noun Kutte "robe" in the four conditions are given in (18), the sentences in which the other items occurred are presented in Appendix B:

(18) a. Viele Mönche tragen die sogenannte Kutte täglich von morgens bis abends. "Many monks wear the so-called robe everyday from morning to night."

b. Viele Mönche tragen die sogenannte „Kutte“ täglich von morgens bis abends. "Many monks wear the so-called 'robe' everyday from morning to night." 
c. Viele Mönche tragen die wohlbekannte Kutte täglich von morgens bis abends.

"Many monks wear the well-known robe everyday from morning to night."

d. Viele Mönche tragen die wohlbekannte „Kutte" täglich von morgens bis abends.

"Many monks wear the well-known 'robe' everyday from morning to night."

The nouns appeared in the same and in a central position in all sentences. The sentence was identical for $(18 \mathrm{a})$ and $(18 \mathrm{~b})$ on the one hand and for (18c) and (18d) on the other hand, except for the fact that the noun was not surrounded by quotation marks in (18a) and (18c) but was in (18b) and (18d). Also, the sentences containing a name-informing modifier (18a and 18b) were identical to the sentences without name-informing modifier (18c and 18d), the only difference being the adjective (sogenannte vs. wohlbekannte). The central semantic difference between the two is that only sogenannte lexically entails reference to the (conventionalized) linguistic shape of the head noun's name, which wohlbekannte does not entail. ${ }^{8}$ The two adjectives were controlled for potentially confounding variables. They have the same number of morphemes and syllables, and the same stress pattern. Further, the four segments immediately preceding the target nouns were identical ([antə]). Note that all nouns have feminine gender; therefore, the two adjectives always ended with the same inflectional suffix, a schwa, and with the same open syllable, namely with [tə]. The syntactic structure of the sentences with sogenannte and those with wohlbekannte was identical.

4.2.2.3 Procedure. The procedure of Experiment I was used in Experiment II as well.

4.2.3 Data analysis9. The data analysis was identical to that of Experiment I with the exception of two aspects. First, in Experiment II, acoustic effects were analyzed at more places than in Experiment I. Remember that the data analysis of Experiment I was restricted to the first and stressed syllable of the target nouns. In Experiment II, the test sentences were constructed in a way that allowed for further analyses and ensured the comparability of the analyses. Specifically, we analyzed the four areas: (a) voiceless plosive plus vowel before the target noun/before the first quotation marks; (b) voiceless plosive plus vowel of the first syllable of the target noun/after the first quotation marks; (c) voiceless plosive plus vowel of the second syllable of the target noun/before the second quotation marks; and (d) voiceless plosive plus vowel after the target noun/after the second quotation marks. The four areas are illustrated in (19): ${ }^{10}$

(19) sogenannte „Kutte“ täglich "so-called 'robe' everyday”

Underlined part: to 'kuto te:

Area a: to

Area b: 'ku

Area c: to

Area d: te:

In all of the four aforementioned areas, a voiceless plosive preceded a vowel. In each area, we analyzed the seven dependent variables previously presented in Table 1 (see Section 4.1.3), resulting in 28 analyses in total. ${ }^{11}$

Being comprised of a voiceless plosive and a vowel, all of the four analysis areas were similar to the target area of Experiment I. Hence, the same segmentation criteria were applied here (see Section 4.1.3). The only new case, and a second difference in comparison to the analysis of Experiment 1, was the separation of the nasal [n] in the coda of the penultimate syllable of sogenannte/wohlbekannte and the constriction of the following voiceless alveolar plosive [t]. The border between the two was placed at the point where the energy in the lower frequencies abruptly decreased (Ladefoged, 2003; Machač \& Skarnitzl, 2009). An abrupt decrease in the amplitude of 
the waveform was the second criterion and if the two criteria did not coincide, priority was given to the first one. If the first criterion could not be reliably spotted, the second one was used.

4.2.4 Results. The result section is divided into four subsections, one for each of the four analysis areas.

\section{Area a: Voiceless plosive plus vowel before target noun/before first quotation marks}

A main effect of Quotation marks was found for two of the seven dependent variables: $\mathbf{D}_{\mathbf{S}}, F 1(1$, $45)=5.26, p=.027 ; F 2(1,21)=17.81, p<.001 ; \mathbf{D}_{\mathrm{C}}, F 1=\mathrm{ns} ; F 2(1,21)=9.09, p=.007$. That is, the syllable [to] and the constriction of the onset plosive were pronounced with a longer duration if quotation marks followed this syllable in comparison to the counterpart without quotation marks. Further, the analysis revealed a main effect of Name-informing context for six of the seven dependent variables: $\mathbf{D}_{\mathbf{S}}, F 1(1,45)=9.98, p=.003 ; F 2(1,21)=38.21, p<.001 ; \mathbf{D}_{\mathbf{P}}$, $F 1(1,45)=23.05, p<.001 ; F 2(1,21)=36.47, p<.001 ; \mathbf{D}_{\mathbf{C}}, F 1(1,45)=17.35, p<.001$; $F 2(1,21)=65.63, p<.001$; VOT, $F 1(1,45)=12.87, p=.001 ; F 2(1,21)=12.87, p=.002$; $\mathbf{F 0 m a x}_{\mathbf{V}}, F 1(1,45)=5.35, p=.025 ; F 2(1,21)=7.45, p=.013 ; \mathbf{I m a x}_{\mathbf{V}}, F 1(1,45)=12.97$, $p=.001 ; F 2(1,21)=21.36, p<.001$. That is, the syllable [to], its plosive, constriction, and VOT were articulated with a longer duration if they were part of the name-informing context in comparison to if they were part of the non-name-informing context. For F0 $\max _{\mathrm{V}}$ and $\operatorname{Imax}_{\mathrm{V}}$, however, higher values were detected in the non-name-informing context. No interaction of Quotation marks $\times$ Name-informing context was detected. Table 4 presents the descriptive statistics of the aforementioned effects (only significant values).

Area b: Voiceless plosive plus vowel of first syllable of target noun/after first quotation marks

A main effect of Quotation marks was found for five of the seven dependent variables: $\mathbf{D}_{\mathbf{S}}, F 1(1$, $45)=67.00, p<.001 ; F 2(1,21)=123.48, p<.001 ; \mathbf{D}_{\mathbf{P}}, F 1(1,45)=112.43, p<.001 ; F 2(1,21)$ $=92.23, p<.001 ; \mathbf{D}_{\mathrm{C}}, F 1(1,45)=46.19, p<.001 ; F 2(1,21)=67.30, p<.001 ;$ VOT, $F 1(1$, $45)=12.37, p=.001 ; F 2(1,21)=7.96, p=.010 ; \mathbf{F 0 m a x}_{\mathbf{V}}, F 1(1,45)=18.79, p<.001 ; F 2(1$, $21)=7.86, p=.011$. That is, nouns with quotation marks were pronounced with a longer first syllable, plosive, constriction, VOT as well as a vowel with a higher F0 $\max _{\mathrm{V}}$ than the same nouns without quotation marks. Further, the analysis revealed a main effect of Name-informing context for one of the seven dependent variables: $\mathbf{D}_{\mathbf{P}}, F 1(1,45)=10.87, p=.002 ; F 2(1,21)=8.12, p=$ .010 . That is, the nouns in a name-informing context were uttered with a longer plosive in the first syllable than the same nouns in a non-name-informing context. No interaction of Quotation marks $\times$ Name-informing context was detected. Table 5 presents the descriptive statistics of the aforementioned effects (only significant values).

Area c: Voiceless plosive plus vowel of second syllable of target noun/before second quotation marks

A main effect of Quotation marks was found for five of the seven dependent variables: $\mathbf{D}_{\mathbf{S}}, F 1(1$, $45)=64.66, p<.001 ; F 2(1,21)=59.89, p<.001 ; \mathbf{D}_{\mathbf{P}}, F 1(1,45)=18.90, p<.001 ; F 2(1,21)$ $=11.48, p=.003 ;$ VOT, $F 1(1,45)=10.30, p=.002 ; F 2(1,21)=9.06, p=.007 ; \mathbf{D}_{\mathbf{V}}, F 1(1,45)$ $=47.73, p<.001 ; F 2(1,21)=61.83, p<.001 ; \mathbf{F 0 m a x}_{\mathbf{V}}, F 1=\mathrm{ns} ; F 2(1,21)=10.60, p=.004$. That is, the syllable and plosive, the VOT of the plosive, the vowel as well as the F0 $\max _{\mathrm{V}}$ were longer/higher if they were (part of) the second syllable of the target noun embraced by quotation 
Table 4. Descriptive statistics (only significant values).

\begin{tabular}{lllllll}
\hline Condition & $D_{S}$ & $D_{P}$ & $D_{C}$ & VOT & FOmax $_{V}$ & Imax $_{V}$ \\
\hline Q & $104(18)$ & & & & \\
NQ & $104(6)$ & & $34(4)$ & & \\
& $100(18)$ & & & & & \\
NIC & $100(6)$ & & $32(4)$ & & & \\
& $105(18)$ & $72(15)$ & $35(7)$ & $37(13)$ & $217(25)$ & $52(3)$ \\
NNIC & $105(6)$ & $72(4)$ & $35(3)$ & $37(2)$ & $217(2)$ & $52(0.5)$ \\
& $99(18)$ & $65(14)$ & $31(8)$ & $34(11)$ & $220(22)$ & $53(3)$ \\
& $99(5)$ & $66(4)$ & $31(3)$ & $34(3)$ & $219(2)$ & $53(0.6)$ \\
\hline
\end{tabular}

First line for each condition: subject analysis (mean, standard deviation in brackets); second line for each condition: item analysis (mean, standard deviation in brackets).

$\mathrm{D}_{\mathrm{S}}$ : duration of syllable (in $\mathrm{ms}$ ); $\mathrm{D}_{\mathrm{p}}$ : duration of plosive (in $\mathrm{ms}$ ); $\mathrm{D}_{\mathrm{C}}$ : duration of constriction of plosive (in ms); VOT: voice onset time of plosive (in ms); FOmax : maximum F0 of vowel (in $\mathrm{Hz}$ ); Imax : maximum intensity of vowel (in $\mathrm{dB}$ ); Q: nouns with quotation marks; NQ: nouns without quotation marks; NIC: name-informing context; NNIC: non-nameinforming context.

Table 5. Descriptive statistics (only significant values).

\begin{tabular}{llllll}
\hline Condition & $D_{S}$ & $D_{\mathrm{P}}$ & $\mathrm{D}_{\mathrm{C}}$ & VOT & F0max \\
\hline $\mathbf{Q}$ & $222(20)$ & $158(12)$ & $84(9)$ & $73(7)$ & $237(28)$ \\
NQ & $223(37)$ & $157(5)$ & $84(9)$ & $73(8)$ & $235(12)$ \\
& $208(18)$ & $147(11)$ & $77(7)$ & $70(7)$ & $231(26)$ \\
NIC & $208(35)$ & $147(7)$ & $77(9)$ & $70(9)$ & $230(12)$ \\
NNIC & & $154(14)$ & & & \\
& & $154(8)$ & & & \\
\hline
\end{tabular}

First line for each condition = Subject analysis (mean, standard deviation in brackets), second line for each condition $=$ Item analysis (mean, standard deviation in brackets).

$\mathrm{D}_{\mathrm{s}}$ : duration of syllable (in $\mathrm{ms}$ ); $\mathrm{D}_{\mathrm{p}}$ : duration of plosive (in $\mathrm{ms}$ ); $\mathrm{D}_{\mathrm{C}}$ : duration of constriction of plosive (in ms); VOT: Voice Onset Time of plosive (in ms); FOmax : maximum F0 of vowel (in Hz); Q: nouns with quotation marks; $\mathrm{NQ}$ : nouns without quotation marks; NIC: name-informing context; NNIC: non-name-informing context.

marks in comparison to the second syllable of the same noun without quotation marks. Moreover, the analysis revealed a main effect of Name-informing context for one of the seven dependent variables: F0max $\mathbf{y}_{\mathbf{V}}, F 1(1,45)=5.12, p=.029 ; F 2(1,21)=10.73, p=.004$. The nucleus of the second syllable of the target noun was articulated with a higher $\mathrm{F} \mathrm{max}_{\mathrm{V}}$ if it occurred with a nameinforming context. No interaction of Quotation marks $\times$ Name-informing context was detected. Table 6 presents the descriptive statistics of the aforementioned effects (only significant values).

\section{Area d: Voiceless plosive plus vowel after target noun/after second quotation marks}

A main effect of Quotation marks was found for five of the seven dependent variables: $\mathbf{D}_{\mathbf{S}}, F 1(1$, $45)=18.07, p<.001 ; F 2(1,21)=15.62, p=.001 ; \mathbf{D}_{\mathbf{P}}, F 1(1,45)=15.78, p<.001 ; F 2(1,21)$ $=9.74, p=.005 ; \mathbf{D}_{\mathbf{C}}, F 1(1,45)=21.62, p<.001 ; F 2(1,21)=26.08, p<.001 ;$ VOT,$F 1(1,45)$ $=6.42, p=.015 ; F 2(1,21)=8.84, p=.007 ; \operatorname{Imax}_{\mathbf{V}}, F 1(1,45)=11.92, p=.001 ; F 2(1,21)=$ $12.34, p=.002$. That is, if quotation marks were present, the following syllable, the plosive, its constriction, and the $\operatorname{Imax}_{\mathrm{V}}$ of the vowel were longer/higher in comparison to the condition without 
Table 6. Descriptive statistics (only significant values).

\begin{tabular}{llllll}
\hline Condition & $D_{S}$ & $D_{P}$ & VOT & $D_{V}$ & FOmax $_{V}$ \\
\hline $\mathbf{Q}$ & $232(36)$ & $114(11)$ & $36(9)$ & $117(33)$ & $254(24)$ \\
& $232(27)$ & $114(5)$ & $36(7)$ & $118(24)$ & $253(10)$ \\
NQ & $212(31)$ & $110(11)$ & $33(8)$ & $102(28)$ & $249(26)$ \\
& $212(30)$ & $109(7)$ & $33(8)$ & $102(25)$ & $249(9)$ \\
NIC & & & & $254(25)$ \\
NNIC & & & & $253(9)$ \\
& & & & & $248(25)$ \\
& & & & & $249(9)$ \\
\hline
\end{tabular}

First line for each condition: Subject analysis (mean, standard deviation in brackets); second line for each condition: Item analysis (mean, standard deviation in brackets).

$D_{\mathrm{s}}$ : duration of syllable (in $\mathrm{ms}$ ); $\mathrm{D}_{\mathrm{p}}$ : duration of plosive (in $\mathrm{ms}$ ); VOT: voice onset time of plosive (in ms); $\mathrm{D}_{\mathrm{V}}$ : duration of vowel (in ms); F0max : maximum F0 of vowel (in $\mathrm{Hz}$ ); Q: nouns with quotation marks; NQ: nouns without quotation marks; NIC: name-informing context; NNIC: non-name-informing context.

Table 7. Descriptive statistics (only significant values).

\begin{tabular}{llllll}
\hline Condition & $D_{S}$ & $D_{P}$ & $D_{C}$ & VOT & $I_{m a x}$ \\
\hline $\mathbf{Q}$ & $26 I(40)$ & $169(22)$ & $97(21)$ & $70(8)$ & $56.2(3)$ \\
& $255(35)$ & $168(17)$ & $94(12)$ & $70(6)$ & $56.2(2)$ \\
NQ & $241(27)$ & $158(14)$ & $83(12)$ & $73(8)$ & $55.6(3)$ \\
& $239(35)$ & $157(16)$ & $83(14)$ & $73(7)$ & $55.6(2)$ \\
\hline
\end{tabular}

First line for each condition: Subject analysis (mean, standard deviation in brackets); second line for each condition: Item analysis (mean, standard deviation in brackets).

$\mathrm{D}_{\mathrm{S}}$ : duration of syllable (in $\mathrm{ms}$ ); $\mathrm{D}_{\mathrm{p}}$ : duration of plosive (in $\mathrm{ms}$ ); $\mathrm{D}_{\mathrm{C}}$ : duration of constriction of plosive (in ms); VOT: voice onset time of plosive (in $\mathrm{ms}$ ); Imax $\mathrm{v}$ : maximum intensity of vowel (in $\mathrm{dB}$ ); Q: nouns with quotation marks; NQ: nouns without quotation marks.

quotation marks. Note that the VOT was slightly shorter if quotation marks were present. No main effect of Name-informing context and no interaction of Quotation marks $\times$ Name-informing context were detected. Table 7 presents the descriptive statistics of the aforementioned effects (only significant values).

4.2.5 Discussion. The second experimental study clearly confirmed the main effect of Quotation marks in the target syllable; that is, in the syllable after the first quotation marks. For the four dependent variables, for which a main effect was found in Experiment I, a main effect was detected here as well. Target syllables, plosives, constrictions, and VOTs of the nouns were longer if the nouns were embraced by quotation marks in the two studies. Also, the two dependent variables that did not show a main effect in Experiment I, namely vowel duration and the maximum intensity of the vowel, did not show an effect in Experiment II either. Only the maximum F0 of the vowel showed different patterns in the two studies: Whereas it was not higher in quoted nouns in Experiment I, it was in Experiment II. Based on these results, it can be stated that syllables are longer if they are preceded by quotation marks; in particular, the syllable onset, the plosive (both the constriction and the VOT), is lengthened if items are quoted.

In contrast to Experiment I, Experiment II also looked at three other areas, all of which were affected by the presence of quotation marks. So, if quotation marks occur, the syllable before the 
target noun/before the first quotation marks (Area a), the first syllable of the target noun/the syllable after the first quotation marks (Area b), the second syllable of the target noun/the syllable before the second quotation marks (Area c), and the syllable after the target noun/after the second quotation marks (Area d) are all articulated differently in comparison to if no quotation marks appear in the sentence. While the syllable and constriction duration were longer in Area a if quotes were contained in the test sentences, the syllable, plosive, VOT, vowel, and maximum F0 were longer/higher in Area c. Finally, in Area d, the syllable, plosive, constriction, and maximum intensity were longer/higher. In sum, quotation marks are clearly pronounced, not only within the quoted noun but also in the parts preceding and following this noun.

As outlined in the discussion of Experiment I, the main effect of Name-informing context found in the first study had to be treated with caution as syntactic and discourse-related aspects differed between name-informing and non-name-informing contexts. In Experiment II, these shortcomings were removed and the contexts were entirely comparable. An effect was detected for the plosive of the first syllable of the target noun (Area b), which was longer in name-informing than in nonname-informing contexts. However, the name-informing context was primarily pronounced before the target noun (Area a) as the syllable, plosive, constriction, VOT, maximum F0, and maximum intensity were longer/higher than in non-name informing contexts. In the second syllable of the target noun (Area c), similar to Area b, only one variable showed an effect in that a higher maximum F0 was detected in name-informing contexts. No effect was found after the target noun (Area d). In sum, the name informing seems to be primarily encoded before the noun whose naming status has to be introduced, partly within the noun itself, but not after the noun.

Although a significant interaction between the two independent factors was found in Experiment I, this could not be confirmed in the second study. Hence, we conclude that no clear and systematic interaction between Quotation marks $\times$ Name-informing context is effective.

\section{General discussion and conclusion}

The semantics and pragmatics of quotation have been extensively discussed in the literature. Whether quotation, which can be expressed by several well-known markers in written language, also has correlates in spoken language is far less clear. Most research that considered quotation in spoken discourse focused on direct and indirect quotation and revealed, overall, mixed results. The present article is the first contribution that investigated acoustic correlates of a different type of quotation in a systematic and sound manner. In both empirical studies presented above, clear effects were found.

Quotation marks have been argued to represent pragmatic markers that indicate that the item of interest has to be interpreted in a non-standard way. They signal, for instance, that reference is made to something that goes beyond the standard denotation of an expression. In name-informing quotation, quotes inform the addressee about the fact that the target is used as a conventionalized name of a specific lexical concept. The present contribution shows that quotation marks are perceived by speakers as linguistically relevant markers and, as such, encoded on the articulatory level. The pragmatic function of quotation marks is well attested in the literature (see Section 2.2) and our results indicate that using quotes is not only a stylistic phenomenon (see, e.g., Gutzman \& Stei, 2011, p. 2660) but is materially manifested in the speech production process.

Observe that the results of our study are not compatible with approaches that implement quotation marks and their acoustic equivalents as an essential part of a quotational construction and its semantic compositional representation (see Section 2.1 for discussion). The absence of an interaction between the two independent factors indicates that quotation marks are perceived independently of whether they are accompanied by other markers, such as a predicate or a modifier, that point to the name-informing character of a target item. Crucially, in quotational contexts in which 
the target item is not embraced by quotation marks an acoustic correlate was not found. This can be explained by the fact that the mentioning use of the target expression is resolved contextually here, resulting in a reduced need for an acoustic encoding. Thus, our results are better compatible with pragmatic approaches towards quotation, like De Brabanter's (2013), which argue for quotation marks not be a necessary ingredient of quotational constructions based on the assumption that quotational meanings can be construed through context.

Further, we believe our results to provide support for approaches that view quotation marks as a pragmatic device used to create markedness of the expression in quotes. Note that the current research, its findings, and implications are exclusively speaker-centered. While Levinson's (2000, pp. 136-137) M-principle relates to the interaction between speaker and hearer (see Section 2.2), the dimension of the speaker is in focus in the domain under discussion. The speaker's task is to "indicate an abnormal, nonstereotypical situation by using marked expressions that contrast with those you would use to describe the corresponding normal, stereotypical situation." In the present case, the stereotypical situation is instantiated by a denotational use of a noun, as relevant in non-nameinforming contexts without quotation marks (e.g., Viele Mönche tragen die wohlbekannte Kutte täglich von morgens bis abends. "Many monks wear the well-known robe everyday from morning to night"). In the corresponding non-stereotypical situation (e.g., Viele Mönche tragen die wohlbekannte ,Kutte “ täglich von morgens bis abends. "Many monks wear the well-known 'robe' everyday from morning to night"), in turn, the linguistic side of Kutte, its shape as well as its use as a conventionalized name, is pointed at by relying on a marked version of the realization of Kutte; for instance, the noun with a lengthened first syllable, specifically a lengthened onset of this syllable.

In a name-informing context, the stereotypical situation does not designate the common denotation of, for instance, the noun Kutte; instead, reference to and emphasis of the form of the noun and its use as a conventionalized name of a lexical concept represent the default situation (e.g., Viele Mönche tragen die sogenannte Kutte täglich von morgens bis abends. "Many monks wear the socalled robe everyday from morning to night"). That means, a name-informing predicate or modifier triggers this interpretation by default and realizes the name mentioning lexically. The non-default situation, the situation in which quotation marks are used (e.g., Viele Mönche tragen die sogenannte ,Kutte“ täglich von morgens bis abends. "Many monks wear the so-called 'robe' everyday from morning to night"), is then a kind of an additional marker, an extra emphasis, a double mention, or a double name-informing strategy that serves to underline the intended interpretation and guarantee it by using a double strategy (see Finkbeiner, 2015, p. 164; see also Levinson, 2000, p. 137).

In conclusion, the two experimental studies reported in Section 4 clearly show that speakers articulate quotation marks and provide robust evidence for the existence of acoustic correlates of quotation marks.

\section{Acknowledgements}

We are grateful to Marzena Zygis, the editors Cynthia Clopper and Holger Mitterer, the associate editor Pilar Prieto, and the three anonymous reviewers of Language and Speech for their constructive feedback on previous versions of the article. Also, we wish to thank the audiences at the Institut für Deutsche Sprache (IDS, Mannheim, 2019), of the workshop "The Relation Between Prosodic and Referential Structure" held at the 40th Annual Conference of the German Linguistic Society (DGfS, Stuttgart, 2018), and of the conferences Architectures and Mechanisms for Language Processing (AMLaP, Berlin, 2018), Phonetics and Phonology in Europe (PaPE, Lecce, 2019), and the 52nd Annual Meeting of the Societas Linguistica Europaea (SLE, Leipzig, 2019) for fruitful discussions and helpful comments on the topic of the current paper.

\section{Funding}

The author(s) received no financial support for the research, authorship, and/or publication of this article. 


\section{ORCID iD}

Marcel Schlechtweg (iD) https://orcid.org/0000-0001-5312-4929

\section{Notes}

1. Note that we assume a notional difference between name mentioning and name informing (see also Härtl, 2018). Name mentioning is the hypernym with the two hyponyms name informing and distancing. Name informing is illustrated in the examples above. Distancing, in turn, means that a language user departs from the usual denotation of an expression, as in Ann had a very bad experience at the so-called "hotel," where the accommodation did not match the speaker's expectations of a usual hotel. Thus, hotel is interpreted in an ironic way here. For discussion, see also Section 2.1.

2. The notion of name as used in the current paper relates to the lexical-conceptual representation of a common noun and the label used for it (see, e.g., Bücking, 2010; Härtl, 2016, for detailed considerations). Proper names are excluded from the current investigation.

3. The fact that the head noun of a so-called-construction is mentioned and used denotationally at the same time brings the construction close to what is known as mixed quotation in the literature (see Davidson, 1979). Observe, however, that, in mixed quotation, direct and indirect speech reports are usually combined in one utterance (see $3 \mathrm{~d}$ above). This is not the case in the construction under discussion.

4. Note that, to the best of our knowledge, there are no systematic analyses of the spread of different typographic means.

5. Note that we ignore distancing name mentioning as in Ann had a very bad experience at the so-called "hotel" here. It is assumed that the nouns of low frequency and the test sentences used in the present investigation are exclusively compatible with name informing (see also Section 2.2).

6. All test sentences contain NPs supporting kind reference. In certain contexts, definite NPs may give rise to an ambiguity between generic (i.e., kind) and specific readings (cf. The gray parrot (Alex) has symbolic intelligence). As this aspect, however, does not affect the testability of the critical feature in question, we do not include it in the further analysis.

7. Note that all of the 256 sound files ( 8 subjects $x 32$ sound files per subject) were kept for the analyses.

8. A reviewer pointed out that wohlbekannte also implies knowledge about the conventionalized name of the head noun's denotatum. However, we believe this meaning to be derived through a pragmatic implicature, which is also why it can be cancelled, cf. Die wohlbekannte/?'sogenannte Epicondylitis ist unter Sportlern gefürchtet, aber niemand bezeichnet diese Krankheit so ("The well-known/so-called epicondylitis is feared amongst athletes but nobody refers to it like that").

9. This time, two of the 512 original sound files ( 16 subjects $x 32$ sound files per subject) were not analyzed due to technical problems during the recording process. The other sound files with the same items in the other three conditions uttered by the same speakers were also excluded for reasons of comparability. That is, eight sound files were not considered. After the exclusion of these files and statistical outliers, the final dataset of raw values of each dependent variable included at least $95 \%$ of the original data.

10. Note that we did not conduct similar analyses in Experiment I because not all of the areas would have been suitable and comparable here. For instance, the word before the target noun/before the first quotation marks was either, depending on the condition, sie [zi:] or die [di:]. Since the syllable onsets/words were not identical and coarticulation affected the realization of the high front vowel, we decided to ignore these analyses in Experiment I. In Experiment II, the four areas as well as the preceding and following contexts were identical across all conditions.

11. Note that the sequence of the voiceless plosive and the vowel always constituted a syllable in Areas a through c. In Area d, in contrast, the sequence sometimes represented only the onset and nucleus. For reasons of comparability, the coda of the syllable was not taken into consideration in Area d.

\section{References}

Bennett, J. (1988). Quotation. Noûs, 22, 399-418.

Bertrand, R., \& Espesser, R. (2002). Voice diversity in conversation: A case study. In B. Bel \& I. Marlien (Eds.), Speech prosody 2002 (pp. 171-174). Aix-en-Provence, France: ISCA Archive. 
Boersma, P., \& Weenink, D. (2017). Praat: Doing phonetics by computer (Version 6.0.36). [Computer program]. Retrieved from http://www.praat.org/.

Brendel, E., Meibauer, J., \& Steinbach, M. (2011a). Exploring the meaning of quotation. In E. Brendel, J. Meibauer, \& M. Steinbach (Eds.), Understanding quotation (Mouton Series in Pragmatics 7) (pp. 1-33). Berlin, Germany: De Gruyter Mouton.

Brendel, E., Meibauer, J., \& Steinbach, M. (Eds.). (2011b). Understanding quotation (Mouton Series in Pragmatics 7). Berlin, Germany: De Gruyter Mouton.

Bücking, S. (2010). German nominal compounds as underspecified names for kinds. In S. Olsen (Ed.), New impulses in word-formation (pp. 253-281). Hamburg, Germany: Buske.

Cappelen, H., \& Lepore, E. (1999). Using, mentioning and quoting: A reply to Saka. Mind, 108, 741-750.

Cappelen, H., \& Lepore, E. (2007). Language turned on itself: The semantics and pragmatics of metalinguistic discourse. Oxford, UK: Oxford University Press.

Cappelen, H., \& Lepore, E. (2012). Quotation. Stanford Encyclopedia of Philosophy. Stanford, CA: Metaphysics Research Lab.

Cervone, A., Lai, C., Pareti, S., \& Bell, P. (2015). Towards automatic detection of reported speech in dialogue using prosodic cues. Interspeech 2015: 16th Annual Conference of the International Speech Communication Association (pp. 3061-3065). Dresden, Germany.

Chamberland, C., Saint-Aubin, J., \& Légère, M. A. (2013). The impact of text repetition on content and function words during reading: Further evidence from eye movements. Canadian Journal of Experimental Psychology, 67, 94-99.

Christensen, N. E. (1967). The alleged distinction between use and mention. Philosophical Review, 76, 358-367.

Couper-Kuhlen, E. (1998). Coherent voicing: On prosody in conversational reported speech (Interaction and Linguistic Structures 1). Konstanz, Germany: University of Konstanz.

Cumming, S. (2003). Two accounts of indexicals in mixed quotation. Belgian Journal of Linguistics, 17, $77-88$.

Davidson, D. (1979). Quotation. Theory and Decision, 11, 27-40.

De Brabanter, P. (2013). A pragmaticist feels the tug of semantics: Recanati's "Open quotation revisited". Teorema 32, 129-147.

De Brabanter, P. (2017). Why quotation is not a semantic phenomenon, and why it calls for a pragmatic theory. In I. Depraetere \& R. Salkie (Eds.), Semantics and pragmatics: Drawing a line (Logic, Argumentation \& Reasoning 11) (pp. 227-254). Berlin, Germany: Springer.

Finkbeiner, R. (2015). "Ich kenne da so einen Jungen . . . kennen ist gut, wir waren halt mal zusammen weg.": On the pragmatics and metapragmatics of "X ist gut" in German. In J. Arendholz, W. Bublitz, \& M. Kirner-Ludwig (Eds.), The pragmatics of quoting now and then (Topics in English Linguistics 89) (pp. 147-176). Berlin, Germany: De Gruyter Mouton.

García-Carpintero, M. (2011). Double-duty quotation, conventional implicatures and what is said. In E. Brendel, J. Meibauer, \& M. Steinbach (Eds.), Understanding quotation (Mouton Series in Pragmatics 7) (pp. 107-138). Berlin, Germany: De Gruyter Mouton.

Ginzburg, J., \& Cooper, R. (2014). Quotation via dialogical interaction. Journal of Logic, Language and Information, 23, 287-311.

Grice, H. P. (1975). Logic and conversation. In P. Cole \& J. L. Morgan (Eds.), Syntax and semantics 3: Speech acts (pp. 41-58). New York, NY: Academic Press.

Günthner, S. (1997). Direkte und indirekte Rede in Alltagsgesprächen: Zur Interaktion von Syntax und Prosodie in der Redewiedergabe [Direct and indirect speech in conversations of everyday life: On the interaction of syntax and prosody in speech reproduction]. In P. Schlobinski (Eds.), Syntax des gesprochenen Deutsch [Syntax of spoken German] (pp. 227-262). Opladen, Germany: Westdeutscher Verlag.

Günthner, S. (1999). Polyphony and the "layering of voices" in reported dialogues: An analysis of the use of prosodic devices in everyday reported speech. Journal of Pragmatics, 31, 685-708.

Gutzmann, D., \& Stei, E. (2011). How quotation marks what people do with words. Journal of Pragmatics, 43, 2650-2663.

Harth, M. (2011). Quotation and pictoriality. In E. Brendel, J. Meibauer, \& M. Steinbach (Eds.), Understanding quotation (Mouton Series in Pragmatics 7) (pp. 195-208). Berlin, Germany: De Gruyter Mouton. 
Härtl, H. (2016). Normality at the boundary between word-formation and syntax. Linguistische Berichte Sonderheft, 22, 71-98.

Härtl, H. (2018). Name-informing and distancing "sogenannt" ("so-called"): Name-mentioning and the lexicon-pragmatics interface. Zeitschrift für Sprachwissenschaft, 37, 139-169.

Jansen, W., Gregory, M. L., \& Brenier, J. M. (2001). Prosodic correlates of directly reported speech: Evidence from conversational speech. Prosody in speech recognition and understanding (Paper 14). Red Bank, NJ.

Kasimir, E. (2008). Prosodic correlates of subclausal quotation marks. ZAS Papers in Linguistics, 49, 67-77.

Klewitz, G., \& Couper-Kuhlen, E. (1999). QUOTE - UNQUOTE? The role of prosody in the contextualization of reported speech sequences (Interaction and Linguistic Structures 12). Konstanz, Germany: University of Konstanz.

Klockow, R. (1978). Anführungszeichen, Norm und Abweichung [Quotation marks, norm, and deviation]. Linguistische Berichte, 57, 14-24.

Klockow, R. (1980). Linguistik der Gänsefüßchen: Untersuchungen zum Gebrauch der Anführungszeichen im gegenwärtigen Deutsch [The linguistics of quotation marks: Investigations on the use of quotation marks in contemporary German]. Frankfurt/Main, Germany: Haag \& Herchen.

Kunter, G. (2011). Compound stress in English: The phonetics and phonology of prosodic prominence (Linguistische Arbeiten 539). Berlin, Germany: De Gruyter.

Kupisch, T., \& Lleó, C. (2017). Voice onset time in German-Italian simultaneous bilinguals: Evidence on cross-language influence and markedness. In M. Yavaş, M. Kehoe, \& W. Cardoso (Eds.), RomanceGermanic bilingual phonology (Studies in Phonetics and Phonology) (pp. 79-98). Leeds, UK: Equinox.

Ladefoged, P. (2003). Phonetic data analysis: An introduction to fieldwork and instrumental techniques. Malden, MA: Blackwell.

Lampert, M. (2018). "Speaking" quotation marks: Towards a multimodal analysis of quoting verbatim in English. Bern, Switzerland: Peter Lang.

Larson-Hall, J. (2010). A guide to doing statistics in second language research using SPSS. New York, NY: Routledge.

Lehiste, I. (1970). Suprasegmentals. Cambridge, MA: MIT Press.

Lein, T., Kupisch, T., \& van de Weijer, J. (2016). Voice onset time and global foreign accent in GermanFrench simultaneous bilinguals during adulthood. International Journal of Bilingualism, 20, 732-749.

Levinson, S. C. (2000). Presumptive meanings: The theory of generalized conversational implicature. Cambridge, MA: MIT Press.

Lisker, L., \& Abramson, A. S. (1964). A cross-language study of voicing in initial stops: Acoustical measurements. Word, 20, 384-422.

Lisker, L., \& Abramson, A. S. (1967). Some effects of context on voice onset time in English stops. Language and Speech, 10, 1-28.

Ludwig, K., \& Ray, G. (2017). Unity in the variety of quotation. In P. Saka \& M. Johnson (Eds.), The Semantics and Pragmatics of Quotation (Perspectives in Pragmatics, Philosophy \& Psychology 15) (pp. 99-134). Berlin, Germany: Springer.

Machač, P., \& Skarnitzl, R. (2009). Principles of phonetic segmentation. Prague, Czech Republic: Epocha Publishing House.

Maier, E. (2014). Pure quotation. Philosophy Compass, 9, 615-630.

McCullagh, M. (2007). Understanding mixed quotation. Mind, 116, 927-946.

Meibauer, J. (2007). Syngrapheme als pragmatische Indikatoren: Anführung und Auslassung [Syngraphemes as pragmatic indicators: Quotation and omission]. In S. Döring \& J. Geilfuß-Wolfgang (Eds.), Von der Pragmatik zur Grammatik [From pragmatics to grammar] (pp. 21-37). Leipzig, Germany: Leipziger Universitätsverlag.

Oliveira, M. Jr. \& Cunha, D. A. C. (2004). Prosody as marker of direct reported speech boundary. In B. Bel \& I. Marlien (Eds.), Speech Prosody 2004 (pp. 263-266). Nara, Japan: ISCA Archive.

Pätzold, M., \& Simpson, A. P. (1997). Acoustic analysis of German vowels in the Kiel Corpus of Read Speech. In A. P. Simpson, K. J. Kohler, \& T. Rettstadt (Eds.), The Kiel Corpus of Read/Spontaneous Speech: Acoustic data base, processing tools and analysis results (pp. 215-247). Kiel, Germany: University of Kiel. 
Predelli, S. (2003). Scare quotes and their relation to other semantic issues. Linguistics and Philosophy, 26(1), $1-28$.

Quassdorf, S. (2016). “A little more than kin": Quotations as a linguistic phenomenon: A study based on Shakespeare's Hamlet. Freiburg, Germany: Albert-Ludwigs-Universität Freiburg.

Quine, W.O. (1981). Mathematical logic (rev. ed.). Cambridge, MA: Harvard University Press.

Recanati, F. (2001). Open quotation. Mind, 110, 637-687.

Reetz, H., \& Jongman, A. (2009). Phonetics: Transcription, production, acoustics, and perception. Malden, MA: Wiley-Blackwell.

Saka, P. (1998). Quotation and the use-mention distinction. Mind, 107, 113-135.

Saka, P., \& Johnson, M. (Eds.). (2017). The semantics and pragmatics of quotation. Berlin, Germany: Springer.

Sams, J. (2010). Quoting the unspoken: An analysis of quotations in spoken discourse. Journal of Pragmatics, 42, 3147-3160.

Schumacher, P. B., Brandt, P., \& Weiland-Breckle, H. (2018). Online processing of "real" and "fake": The cost of being too strong. In: E. Castroviejo, L. McNally, \& G. Weidman Sassoon (Eds.), The semantics of gradability, vagueness, and scale structure: Experimental perspectives (pp. 93-111). Heidelberg, Germany: Springer.

Simchen, O. (1999). Quotational mixing of use and mention. Philosophical Quarterly, 49, 325-336.

Terken, J., \& Hermes, D.J. (2000). The perception of prosodic prominence. In M. Horne (Ed.), Prosody: Theory and experiment: Studies presented to Gösta Bruce (pp. 89-127). Dordrecht, The Netherlands: Kluwer Academic Publishers.

Turk, A., Nakai, S., \& Sugahara, M. (2006). Acoustic segment durations in prosodic research: A practical guide. In S. Sudhoff, D. Lenertová, R. Meyer, S. Pappert, P. Augurzky, I. Mleinek, N. Richter, \& J. Schließer (Eds.), Methods in empirical prosody research (Language, Context, and Cognition 3) (pp. 1-27). Berlin, Germany: Walter de Gruyter.

Umbach, C., \& Gust, H. (2014). Similarity demonstratives. Lingua, 149(A), 74-93.

Wang, X. (2018). Quotation and truth-conditional pragmatics (Frontiers in Applied Linguistics 2). New York, NY: Routledge.

Washington, C. (1992). The Identity Theory of quotation. Journal of Philosophy, 89, 582-605.

\section{Appendix}

\section{Appendix A: Context and target sentences of Experiment I}

(1) a. Diese Blütenknospen werden in Essig oder Öl eingelegt.

Man nennt sie Kapern in vielen Regionen.

"These flower buds are pickled in vinegar or oil.

One calls them capers in many regions."

b. Diese Blütenknospen werden in Essig oder Öl eingelegt.

Man nennt sie „, Kapern “ in vielen Regionen.

"These flower buds are pickled in vinegar or oil.

One calls them 'capers' in many regions."

c. Diese Blütenknospen werden in Essig oder Öl eingelegt.

Man kennt die Kapern in vielen Regionen.

"These flower buds are pickled in vinegar or oil.

One knows the capers in many regions."

d. Diese Blütenknospen werden in Essig oder Öl eingelegt.

Man kennt die ,, Kapern “ in vielen Regionen.

"These flower buds are pickled in vinegar or oil.

One knows the "capers' in many regions."

(2) a. Eine bestimmte Baumart findet sich häufig an Flussufern.

Man nennt sie Pappel im deutschsprachigen Raum.

"A specific kind of tree is often found at river banks.

One calls it poplar in the German-speaking world." 
b. Eine bestimmte Baumart findet sich häufig an Flussufern.

Man nennt sie „Pappel“ im deutschsprachigen Raum.

"A specific kind of tree is often found at river banks.

One calls it "poplar' in the German-speaking world."

c. Eine bestimmte Baumart findet sich häufig an Flussufern.

Man kennt die Pappel im deutschsprachigen Raum.

"A specific kind of tree is often found at river banks.

One knows the poplar in the German-speaking world."

d. Eine bestimmte Baumart findet sich häufig an Flussufern.

Man kennt die ,Pappel“ im deutschsprachigen Raum.

"A specific kind of tree is often found at river banks.

One knows the "poplar' in the German-speaking world."

(3) a. In bestimmten Klöstern gehört eine braune Tunika zur Grundausstattung.

Man nennt sie Kutte in Ordenskreisen.

"In specific monasteries a brown tunic is part of the basic equipment.

One calls it robe among monks."

b. In bestimmten Klöstern gehört eine braune Tunika zur Grundausstattung.

Man nennt sie „Kutte“ in Ordenskreisen.

"In specific monasteries a brown tunic is part of the basic equipment.

One calls it 'robe' among monks."

c. In bestimmten Klöstern gehört eine braune Tunika zur Grundausstattung.

Man kennt die Kutte in Ordenskreisen.

"In specific monasteries a brown tunic is part of the basic equipment.

One knows the robe among monks."

d. In bestimmten Klöstern gehört eine braune Tunika zur Grundausstattung.

Man kennt die ,Kutte“ in Ordenskreisen.

"In specific monasteries a brown tunic is part of the basic equipment.

One knows the 'robe' among monks."

(4) a. Auch in der jüdischen Gemeinde beharrt man auf einer traditionellen Kopfbedeckung.

Man nennt sie Kippa auf der ganzen Welt.

"The Jewish community also insists on a traditional headgear.

One calls it kippah all over the world."

b. Auch in der jüdischen Gemeinde beharrt man auf einer traditionellen Kopfbedeckung.

Man nennt sie „Kippa“ auf der ganzen Welt.

"The Jewish community also insists on a traditional headgear.

One calls it 'kippah' all over the world."

c. Auch in der jüdischen Gemeinde beharrt man auf einer traditionellen Kopfbedeckung.

Man kennt die Kippa auf der ganzen Welt.

"The Jewish community also insists on a traditional headgear.

One knows the kippah all over the world."

d. Auch in der jüdischen Gemeinde beharrt man auf einer traditionellen Kopfbedeckung.

Man kennt die ,Kippa“ auf der ganzen Welt.

"The Jewish community also insists on a traditional headgear.

One knows the "kippah' all over the world."

(5) a. Eine Weidewiese dient oft als Futtergrundlage für Kühe und Schafe.

Man nennt sie Koppel in der Landwirtschaft.

"A pasture often serves as feeding basis for cows and sheep.

One calls it paddock in agriculture."

b. Eine Weidewiese dient oft als Futtergrundlage für Kühe und Schafe.

Man nennt sie „Koppel“ in der Landwirtschaft.

"A pasture often serves as feeding basis for cows and sheep.

One calls it "paddock' in agriculture."

c. Eine Weidewiese dient oft als Futtergrundlage für Kühe und Schafe.

Man kennt die Koppel in der Landwirtschaft.

"A pasture often serves as feeding basis for cows and sheep.

One knows the paddock in agriculture."

d. Eine Weidewiese dient oft als Futtergrundlage für Kühe und Schafe.

Man kennt die ,Koppel “ in der Landwirtschaft. 
"A pasture often serves as feeding basis for cows and sheep.

One knows the 'paddock' in agriculture."

(6) a. Zum Glück leben nur noch wenige Menschen in dieser kleinen ärmlichen Unterkunft aus Holz. Man nennt sie Kate in manchen Teilen Deutschlands.

"Fortunately, only a few people still live in this small and poor accommodation made of wood. One calls it cottage in some parts of Germany."

b. Zum Glück leben nur noch wenige Menschen in dieser kleinen ärmlichen Unterkunft aus Holz. Man nennt sie „Kate “in manchen Teilen Deutschlands.

"Fortunately, only a few people still live in this small and poor accommodation made of wood. One calls it 'cottage' in some parts of Germany."

c. Zum Glück leben nur noch wenige Menschen in dieser kleinen ärmlichen Unterkunft aus Holz. Man kennt die Kate in manchen Teilen Deutschlands.

"Fortunately, only a few people still live in this small and poor accommodation made of wood. One knows the cottage in some parts of Germany."

d. Zum Glück leben nur noch wenige Menschen in dieser kleinen ärmlichen Unterkunft aus Holz. Man kennt die „Kate“ in manchen Teilen Deutschlands.

"Fortunately, only a few people still live in this small and poor accommodation made of wood. One knows the 'cottage' in some parts of Germany."

(7) a. Diese korbähnliche Transporttasche für den Rücken erleichtert die Arbeit in der Landwirtschaft. Man nennt sie Kiepe unter Bauern.

"This basket-like bag for the back facilitates the work in agriculture.

One calls it pannier among farmers."

b. Diese korbähnliche Transporttasche für den Rücken erleichtert die Arbeit in der Landwirtschaft. Man nennt sie ,Kiepe “ unter Bauern.

"This basket-like bag for the back facilitates the work in agriculture.

One calls it "pannier' among farmers."

c. Diese korbähnliche Transporttasche für den Rücken erleichtert die Arbeit in der Landwirtschaft. Man kennt die Kiepe unter Bauern.

"This basket-like bag for the back facilitates the work in agriculture.

One knows the pannier among farmers."

d. Diese korbähnliche Transporttasche für den Rücken erleichtert die Arbeit in der Landwirtschaft. Man kennt die „Kiepe“ unter Bauern.

"This basket-like bag for the back facilitates the work in agriculture.

One knows the 'pannier' among farmers."

(8) a. Insektenlarven werden von einer robusten Hülle geschützt.

Man nennt sie Puppe in der Zoologie.

"Insect larvae are protected by a robust shell. One calls it cocoon in zoology."

b. Insektenlarven werden von einer robusten Hülle geschützt.

Man nennt sie „, Puppe “ in der Zoologie.

"Insect larvae are protected by a robust shell.

One calls it 'cocoon' in zoology."

c. Insektenlarven werden von einer robusten Hülle geschützt.

Man kennt die Puppe in der Zoologie.

"Insect larvae are protected by a robust shell. One knows the cocoon in zoology."

d. Insektenlarven werden von einer robusten Hülle geschützt.

Man kennt die „Puppe“ in der Zoologie.

"Insect larvae are protected by a robust shell.

One knows the 'cocoon' in zoology."

\section{Appendix B: Sentences of Experiment II}

(1) a. Manche Kinder mögen die sogenannte Kaper tatsächlich sehr. "Some children like the so-called caper really a lot."

b. Manche Kinder mögen die sogenannte ,, Kaper " tatsächlich sehr.

"Some children like the so-called "caper' really a lot."

c. Manche Kinder mögen die wohlbekannte Kaper tatsächlich sehr.

"Some children like the well-known caper really a lot." 
d. Manche Kinder mögen die wohlbekannte „Kaper“ tatsächlich sehr.

"Some children like the well-known 'caper' really a lot."

(2) a. Einige Vogelarten nutzen die sogenannte Pappel tagelang als Rastplatz.

"Some kinds of birds use the so-called poplar several days as rest area."

b. Einige Vogelarten nutzen die sogenannte „, Pappel“ tagelang als Rastplatz. "Some kinds of birds use the so-called 'poplar' several days as rest area."

c. Einige Vogelarten nutzen die wohlbekannte Pappel tagelang als Rastplatz. "Some kinds of birds use the well-known poplar several days as rest area."

d. Einige Vogelarten nutzen die wohlbekannte „Pappel “ tagelang als Rastplatz. "Some kinds of birds use the well-known 'poplar' several days as rest area."

(3) a. Viele Mönche tragen die sogenannte Kutte täglich von morgens bis abends. "Many monks wear the so-called robe everyday from morning to night."

b. Viele Mönche tragen die sogenannte „Kutte " täglich von morgens bis abends. "Many monks wear the so-called 'robe' everyday from morning to night."

c. Viele Mönche tragen die wohlbekannte Kutte täglich von morgens bis abends. "Many monks wear the well-known robe everyday from morning to night."

d. Viele Mönche tragen die wohlbekannte „Kutte " täglich von morgens bis abends. "Many monks wear the well-known 'robe' everyday from morning to night."

(4) a. Pferdebesitzer verwenden die sogenannte Koppel typischerweise für die Freilandhaltung ihrer Tiere. "Horse owners use the so-called paddock typically as an outside place for their animals."

b. Pferdebesitzer verwenden die sogenannte „, Koppel “ typischerweise für die Freilandhaltung ihrer Tiere. "Horse owners use the so-called 'paddock' typically as an outside place for their animals."

c. Pferdebesitzer verwenden die wohlbekannte Koppel typischerweise für die Freilandhaltung ihrer Tiere. "Horse owners use the well-known paddock typically as an outside place for their animals."

d. Pferdebesitzer verwenden die wohlbekannte „, Koppel“ typischerweise für die Freilandhaltung ihrer Tiere. "Horse owners use the well-known 'paddock' typically as an outside place for their animals."

(5) a. Männliche Juden tragen die sogenannte Kippa tagtäglich in der Synagoge.

"Male Jews wear the so-called kippah everyday in the synagogue."

b. Männliche Juden tragen die sogenannte ,Kippa “ tagtäglich in der Synagoge. "Male Jews wear the so-called 'kippah' everyday in the synagogue."

c. Männliche Juden tragen die wohlbekannte Kippa tagtäglich in der Synagoge.

"Male Jews wear the well-known kippah everyday in the synagogue."

d. Männliche Juden tragen die wohlbekannte ,Kippa “ tagtäglich in der Synagoge.

"Male Jews wear the well-known 'kippah' everyday in the synagogue."

(6) a. Etliche Türkeiliebhaber essen die sogenannte Pita täglich in ihrem Urlaub. "Quite a few fans of Turkey eat the so-called pita everyday during their vacation."

b. Etliche Türkeiliebhaber essen die sogenannte „Pita“ täglich in ihrem Urlaub. "Quite a few fans of Turkey eat the so-called "pita' everyday during their vacation."

c. Etliche Türkeiliebhaber essen die wohlbekannte Pita täglich in ihrem Urlaub. "Quite a few fans of Turkey eat the well-known pita everyday during their vacation."

d. Etliche Türkeiliebhaber essen die wohlbekannte „Pita“ täglich in ihrem Urlaub. "Quite a few fans of Turkey eat the well-known "pita' everyday during their vacation."

(7) a. Bergsteiger erklimmen die sogenannte Kuppe typischerweise ohne Probleme. "Mountaineers reach the so-called tip typically without problems."

b. Bergsteiger erklimmen die sogenannte „Kuppe " typischerweise ohne Probleme. "Mountaineers reach the so-called 'tip' typically without problems."

c. Bergsteiger erklimmen die wohlbekannte Kuppe typischerweise ohne Probleme. "Mountaineers reach the well-known tip typically without problems."

d. Bergsteiger erklimmen die wohlbekannte „Kuppe“ typischerweise ohne Probleme. "Mountaineers reach the well-known "tip' typically without problems."

(8) a. Nur wenige Musiker spielen die sogenannte Pauke tadellos. "Only a few musicians play the so-called timpani perfectly."

b. Nur wenige Musiker spielen die sogenannte „Pauke“ tadellos. "Only a few musicians play the so-called 'timpani' perfectly."

c. Nur wenige Musiker spielen die wohlbekannte Pauke tadellos. "Only a few musicians play the well-known timpani perfectly."

d. Nur wenige Musiker spielen die wohlbekannte „Pauke“ tadellos. "Only a few musicians play the well-known 'timpani' perfectly." 